NBER WORKING PAPER SERIES

\title{
THE ROLE OF GOVERNMENT AND PRIVATE INSTITUTIONS IN CREDIT CYCLES IN THE U.S. MORTGAGE MARKET
}

\author{
Manuel Adelino \\ William B. McCartney \\ Antoinette Schoar \\ Working Paper 27499 \\ http://www.nber.org/papers/w27499 \\ NATIONAL BUREAU OF ECONOMIC RESEARCH \\ 1050 Massachusetts Avenue \\ Cambridge, MA 02138 \\ July 2020
}

We thank seminar participants at the Bank of Portugal, Boston College, Boston University, the Chinese University of Hong Kong, MIT finance lunch, Nazarbayev University, NBER Corporate Finance Summer Institute and our discussant Claudia Robles-Garcia, New York Fed, NOVA School of Business and Economics, Philadelphia Fed, SFS Cavalcade and our discussant Gonzalo Maturana, UCLA finance lunch, and the Wabash River Finance Conference and our discussant Alexei Tchistyi, as well as Ed Golding, Barney Hartman-Glaser and Christopher Palmer for helpful comments. We thank Yuting Wang for outstanding research assistance. The views expressed herein are those of the authors and do not necessarily reflect the views of the National Bureau of Economic Research.

NBER working papers are circulated for discussion and comment purposes. They have not been peer-reviewed or been subject to the review by the NBER Board of Directors that accompanies official NBER publications.

(C) 2020 by Manuel Adelino, William B. McCartney, and Antoinette Schoar. All rights reserved. Short sections of text, not to exceed two paragraphs, may be quoted without explicit permission provided that full credit, including $(\odot$ notice, is given to the source. 
The Role of Government and Private Institutions in Credit Cycles in the U.S. Mortgage Market Manuel Adelino, William B. McCartney, and Antoinette Schoar

NBER Working Paper No. 27499

July 2020

JEL No. E03,G21,G28,G30,R30

\begin{abstract}
$\underline{\text { ABSTRACT }}$
We show that the distribution of combined loan-to-value ratios (CLTVs) for purchase mortgages in the U.S. has been remarkably stable over the last 25 years. But there was a dramatic shift during the housing boom of the 2000s in the provision of high- CLTV loans through private sources, which replaced almost one-for-one the share of high-CLTV loans directly guaranteed by the government, via FHA and VA. Post 2008, FHA/VA loans increased back to 30\% of all purchase mortgages. This substitution between government and privately backed high-CLTV loans holds within ZIP codes, properties and borrower types over the full sample period. We also show that the increase in private high-CLTV lending follows local house price increases rather than preceding them. These findings suggest that the housing boom was not accompanied by a shift towards more high-CLTV loans, and instead favor models that rely on changes in collateral values or broad changes in house price expectations.
\end{abstract}

Manuel Adelino

Fuqua School of Business

Duke University

100 Fuqua Drive

Durham, NC 27708

and NBER

manuel.adelino@duke.edu

William B. McCartney

Purdue University

403 West State Street

West Lafayette, IN 47907

wmccartn@purdue.edu
Antoinette Schoar

MIT Sloan School of Management

100 Main Street, E62-638

Cambridge, MA 02142

and NBER

aschoar@mit.edu 


\section{Introduction}

Housing markets in the United States and many countries around the world have been marked by recurring boom and bust cycles. Several of these episodes, most notably the 2008 financial crisis, are associated with a significant expansion in the amount of mortgage debt that households take on. ${ }^{1}$ A large and influential literature in macroeconomics on the credit channel highlights the role of house prices in creating a multiplier feedback loop for asset values and the broader economy (see Bernanke et al. (1999) and Kiyotaki and Moore (1997)). If contract enforcement is limited, lenders impose loan-to-value (LTV) limits to ensure repayment and discourage strategic default. Higher asset prices allow borrowers to access more credit relative to their income even if LTV ratios stay constant. This increase in debt-to-income (DTI) levels can lead to a higher likelihood of distress following income shocks. More recent leverage cycle models propose that LTV constraints themselves are relaxed in a boom, which allows investors with higher valuations of an asset to bid more aggressively and drive up prices (see, for example, Geanakoplos (2010)). This relaxation of LTVs can increase the likelihood of strategic default if house prices are volatile. Therefore, it is important to analyze the exact nature of the credit relaxation to understand what role credit plays in either amplifying house price bubbles or causing the rise in prices in the first place. $^{2}$

It is by now well understood that during the housing boom of the early 2000 s lenders were willing to relax DTI constraints across the whole income distribution. Prior research has shown that the level of mortgage credit to income rose significantly in the U.S. during this time period especially for the middle class (see, for example, Adelino et al. $(2016,2017)$, Foote and Willen (2018), and Albanesi et al. (2019)). In this paper, we show that this relaxation of DTI constraints did not go hand in hand with a relaxation in LTV constraints

\footnotetext{
${ }^{1}$ Recent work has shown that credit expansions often precede financial crises (Greenwood et al., 2020; Krishnamurthy and Muir, 2017; Mian et al., 2017).

${ }^{2}$ See, for example, Greenwald (2018) for an analysis of the role LTV and DTI constraints play for house price cycles and monetary policy transmission.
} 
in the U.S. We document that the distribution of CLTVs for purchase mortgages, which includes all liens on a property, remained unchanged across home buyers between 1996 and 2015. Loan sizes at origination increased significantly with the housing cycle (driven by the changes in house values), but the CLTV distribution did not become more skewed towards very high-CLTV loans. We focus on CLTVs at the time of home purchase to analyze the role of access to finance in house price formation. It also alleviates the concern of potential bias in appraisals that would affect measurement of CLTV for refinances. ${ }^{3}$

The main reason why CLTVs did not increase during the housing boom is that U.S. households already had access to very high CLTV loans (loans with a CLTV above 95\%) prior to the housing boom via directly government-backed mortgages from the Federal Housing Administration (FHA) and the Department of Veterans Affairs (VA) (see also Glaeser et al. (2012) and Ferreira and Gyourko (2015)). What changed was the source of high-CLTV loans over the boom and bust period. While the share of privately securitized high-CLTV loans for used home purchases increased substantially during the housing boom (in line with Pinto (2010) and Keys et al. (2012)), we show that they replaced one for one the share of equally high CLTV ratio loans backed by FHA and VA. In addition, the shift from government backed to privately supplied high-CLTV loans did not change across ZIP codes, properties or even types of borrowers over our whole sample period. In other words, the ZIP codes and borrower types with a high share of FHA and VA loans in the early 2000s are the same ones where high-CLTV private loans expanded rapidly post-2002 and crowded out FHA/VA loans. These are also the ZIP codes and borrower types where FHA share surged post-2008.

In a second step, we show that the type of collateral backing house purchase transactions was stable over the cycle. The distribution of age and size of houses purchased with FHA/VA versus private, high-CLTV loans is unchanged over time. In addition, we use a

\footnotetext{
${ }^{3}$ Earlier papers have shown that households borrowed heavily against the increase in house prices, increasing current LTVs (Mian and Sufi (2011), Justiniano et al. (2015)), and consumed out of the increased borrowing (Campbell and Cocco (2007), Mian et al. (2013)).
} 
novel application of the repeat-sales methodology (Case and Shiller, 1989) to show similar stability in the use of high-CLTV loans even within properties over time. This approach ensures that the general quality of the asset remains fixed. We find that the same properties are financed with high-CLTV loans from the different sources throughout the whole sample period.

Third, we look at the purchase decisions of individual households to better understand if borrowers using high-CLTV, government loans pre-boom were different from those of privately provided, high-CLTV loans during the boom. We track the borrowing decisions of specific households in North Carolina that move within their county. Consistent with the ZIP code and property evidence, households who used FHA or VA loans between 1996 and 2003 are much more likely to use private-sector loans with CLTVs $\geq 95 \%$ during the 20042007 period, and then to switch back to FHA-VA loans after the boom. Next, using data from both the Credit Risk Insight Servicing McDash (CRISM) and the Survey of Consumer Finances, we show that the debt-to-income of FHA and private, high-CLTV borrowers is very similar in the boom. Finally, we show that the loan performance for the two groups of loans is also the same once we control for geography and credit scores. If the privatesector loans were different in ways unobservable to us, we would expect to see differences in performance, especially in the crisis, but this is not what we find.

One feature of models of leverage cycles (such as Geanakoplos $(1997,2010)$ ) is that highCLTV loans allow more optimistic buyers to bid up asset prices. We explicitly investigate if the composition or access to credit for more optimistic home buyers changed over the boom. We measure a person's "fixed type" of optimism based on her forecasted life expectancy relative to observed characteristics as in Puri and Robinson (2007). Our analysis shows that the fraction of optimists with high-CLTV loans did not increase significantly in the boom, consistent with house buyers of all types participating similarly in high-CLTV loans.

Finally, we analyze if the switch in the provision of loans from FHA/VA to private highCLTV credit might itself be a driver of the house price cycle. Previous research suggests 
that privately supplied high-CLTV loans are quicker to close and are often available with less documentation than FHA/VA loans of equivalent CLTV (LaCour-Little, 2007). We show that the shift to privately supplied high-CLTV loans follows the growth in house prices rather than leading it. Therefore, the areas where prices rose the most saw higher prices before the increase in private high-CLTV share (consistent with the results in Ferreira and Gyourko (2011)). We also use the house price instrument developed by Palmer (2015) and Guren et al. (2018) to isolate house prices changes that are not driven by credit expansion. Using this methdology, We find that, as before, house price increases lead the rise in private high-CLTV loan share.

In addition, the majority of high-CLTV private loans during the boom were made by lenders that were already present at the beginning of the time period and provided borrowers with access to both types of loans. Over the boom period, these lenders significantly reduced their fraction of FHA loans and increased high-CLTV private loans. These results suggest that private high-CLTV loans were available throughout our sample period by the same lenders that also provide FHA loans and lenders did not expand the set of borrowing options that households had.

Our results raise important questions about how to model credit cycles. We show that highly levered loans were available throughout the last two decades, suggesting that the housing boom and subsequent financial crisis cannot be explained by changes in aggregate purchase CLTVs. Instead, lenders expanded credit in proportion to rising house prices and allowed DTI ratios to go up across the population. Our results suggest that the dynamic of the U.S. housing market is in line with models that rely on changes in collateral values (credit cycle models) or broad changes in house price expectations. An influential early literature on credit cycles going back to Bernanke and Gertler (1989) and Kiyotaki and Moore (1997) emphasizes the role of collateral values in creating a multiplier-accelerator feedback channel in models with limited enforcement. ${ }^{4}$ Since firms and households are

\footnotetext{
${ }^{4}$ See Guerrieri and Uhlig (2016) for a review of the literature exploring how credit cycles interact with cycles in house prices.
} 
constrained in how much they can borrow by the value of their assets, an increase in asset values makes it easier to borrow, which improves the productive use of the asset, and, as a result, increases asset values even further. In these models credit facilitates house price increases but does not cause them.

A recent literature on the leverage cycle, see Geanakoplos (1997, 2010), suggests that pro-cyclical fluctuations in loan-to-value (LTV) ratios can be a causal driver of boom-bust cycles in credit markets. The idea is that when volatility is low for an extended time period, lenders might allow higher LTV ratios because they feel more secure stretching the available collateral. If there is a class of buyers who value the asset more highly than others, the relaxation in LTV constraints allows these borrowers to bid prices up. Several recent papers have used changes in the loan-to-value constraint as a modeling device for the credit expansions of the early 2000s (Corbae and Quintin, 2015; Favilukis et al., 2017; Justiniano et al., 2019; Landvoigt et al., 2015). Our results show that the leverage cycle was muted in the U.S. given the specific nature of U.S. mortgage markets, in particular the fact that high-CLTV loans with explicit government backing were available even before the boom. Some models may use looser CLTV limits as a "stand-in" for a broader relaxation of credit constraints, possibly through higher debt-to-income ratios or weaker documentation requirements. But existing work suggests that different constraints bind in different states of the world and have different effects when they do, see Greenwald (2018).

Our work is also related to papers that have looked at the time series of average LTVs in the U.S. population and found stable averages over time. Glaeser et al. (2012) show that down payments did not change in the years between 1998 and 2008 and are therefore an unlikely culprit for the dramatic increase in house prices. Ferreira and Gyourko (2015) also use deeds data to show a time series of combined loan-to-value ratios for prime loans, subprime loans, FHA/VA and small lenders. Adelino et al. (2018) also show that the distribution of purchase CLTVs over time has been stable. Another set of studies has looked specifically at private-label mortgage-backed securities using data from CoreLogic. Demyanyk 
and Van Hemert (2009), Keys et al. (2012), and Gerardi et al. (2008) document the increase in CLTVs for privately securitized mortgages in the early 2000's. Pinto (2010) shows that the share of mortgages purchased by Fannie Mae and Freddie Mac using CLTVs above $97 \%$ increased from $5 \%$ in 1996 to $40 \%$ in $2007 .{ }^{5}$ We build on this prior work by analyzing the substitution effects between FHA/VA guarantees and private sector securitization in supplying high-CLTV loans and its impact on house prices across the distribution of households and properties.

The rest of the paper is structured as follows. Section II explain the institutional background and the data. Section III presents the main results of the CLTV distribution over the credit cycle. Sections IV and V present the results of CLTV changes at the ZIP code and the personal level. In section VI we present results for timing of house price increases and CLTV changes. The lenders providing FHA/VA and private, high-CLTV mortgages are explored in section VII. And finally, section VIII concludes.

\section{Institutional Set up and Data Description}

The government programs designed and operated by the Federal Housing Administration (FHA) and the Veteran's Administration (VA) share several characteristics. They both seek to encourage home ownership among their target populations: low-income, middle-income, and first-time homeowner households for FHA and military families for VA. The FHA has stricter underwriting standards than the VA, requiring FICO scores to be above 580 in order to qualify for minimum 3.5\% down payment, debt-to-income ratios to be below some maximum (31\% front-end, $45 \%$ back-end), and that the borrower buy mortgage insurance from the FHA. Both the FHA and the VA require that the home be the borrower's primary residence and that the borrower has some proof of employment. FHA-insured and VAinsured loans together account for almost all of the loans backed by "the full faith and credit

\footnotetext{
${ }^{5}$ The 2009 FHA Actuarial Study is available here: https://www.hud.gov/sites/documents/DOC_16571.pdf. The actuarial study includes refinance loans and imputes the values for those properties when calculating its loan-to-value ratios. This imputation may lead to measurement error in CLTVs (Aragon et al., 2010).
} 
guarantee of the US Government." ${ }^{\prime 6}$ Kim et al. (2018) provide an in-depth look at the current origination of FHA and VA mortgages, including the institutional details of this market and the role of non-bank mortgage companies. The paper focuses on the implications of the limited amount of capital of those companies on the stability of the financial sector and the potential need for a government bailout in an adverse event.

Securities backed by FHA loans are guaranteed by the U.S. government through the Government National Mortgage Association (Ginnie Mae), while the VA provides partial guarantees and servicers provide the rest. Ginnie Mae provides additional residual protection in case servicers default. Fannie Mae and Freddie Mac (other government-sponsored entities) purchase loans from the issuing lenders and then securitize mortgages they purchase. Ginnie Mae, in contrast, gives lenders approval to make FHA- or VA-loans. The lenders themselves then package their government-guaranteed loans into mortgage-backed securities. These securities are then explicitly guaranteed by Ginnie Mae. Any losses are first covered by the insurance premiums the FHA requires borrowers of its guaranteed loans to purchase. Further losses are covered by the U.S. government.

The underlying argument for the existence of the FHA/VA programs is that they grant qualifying borrowers access to mortgage credit that they would not normally have access to in a world where mortgages are provided only by private markets. This paper shows that the share of high-CLTV loans made by the private market was highly pro-cyclical during the last two decades. Importantly, highly leveraged loans were made before the boom, as well as after the financial crisis, but only by government programs that had an explicit mission to encourage homeownership.

\subsection{Data sources}

We require a data set that satisfies three requirements. First, it must include every loan (including second and third mortgages) that the borrower used to finance the purchase of

\footnotetext{
${ }^{6}$ https://www.hud.gov/hudprograms/Ginnie_Mae_I, accessed August 1, 2019.
} 
their home. Figure A1 shows the incidence of second and third liens over time in the data and their changing importance over the time series. Second, the data must include a value of the home at the time the mortgage was originated. Third, the data set must include the universe of mortgages, and not just those packaged in private-label securities or originated by one bank. The deeds data, kept in county recorder's offices and then collected and published by data company CoreLogic, meet all three of these criteria.

In this project we focus on purchase transactions. An important limitation of the deeds data-and indeed almost every data set on mortgages--is that measures of value are only reliable at the time of purchase. By using the actual sale value of the home, we assuage concerns about bias in appraisal values (which would affect measured CLTVs for refinance loans (Agarwal et al., 2015), (Kruger and Maturana, ming)). One potential solution is to use data from a lender as in Bernstein (2018), but then we no longer observe the universe of loans.

In the deeds data, we cannot observe the income or credit scores of the borrowers. To answer questions that require credit scores and income, we use data from the Credit Risk Insight Servicing McDash (CRISM) data set, developed by Equifax using a proprietary algorithm to match McDash's mortgage servicing records to individual-level Equifax credit data. This data set covers approximately two thirds of first mortgages originated in the market from the second half of 2005 to the end of 2015. McDash contains mortgage characteristics such as mortgage type (FHA, VA, or private), origination month, original loan amount, original property value, credit score at origination, front-end debt-to-income (DTI), and also mortgage performance over time. Furthermore, Equifax keeps track of consumer's liabilities and we can observe the number of both closed-end seconds (CESs) and home equity lines of credit (HELOCs) taken by the individual, as well as the date and the amount of the two largest loans of each type that are active at each month. This allows us to capture all second liens for over $90 \%$ of consumers. We then estimate original CLTV by matching McDash's first mortgages to Equifax's second mortgages taken by the same person at the same month. 
As a final source of data on mortgage debt, house value and borrower income, the paper uses the 1998 through 2016 waves of the Federal Reserve Board Survey of Consumer Finances (SCF). The SCF is a household survey that asks consumers for detailed information about their finances and savings behavior and is conducted every three years as a repeated cross-section. We use these data to construct a debt-to-income (DTI) measure that includes all payments for all mortgage-related debt, as well as questions about personal beliefs that allow us to extract a measure of individual optimism.

\section{Distribution of CLTV over the credit cycle}

Using the deeds data for all U.S. counties covered by CoreLogic, we calculate the CLTV of every purchase loan and whether that loan was an FHA- or VA-guaranteed loan. The CLTV is defined as follows: we sum the loan amounts for each loan, up to three loans, used to finance the purchase and then divide that sum by the sale price. Cash purchases, those that did not use any leverage, are not included in any of the results presented below (the share of cash-only transactions is presented in Figure A2).

\subsection{Stability of the aggregate CLTV distribution}

Figure 1 shows the cumulative distribution function of CLTVs at purchase for all purchase mortgages originated in 1999 (dashed line) and 2006 (solid line). The distributions in 1999 and 2006 are remarkably similar. In 1999, 68\% of all mortgages had CLTVs strictly less than $95 \%$, and this share hardly moves in 2006 when $66 \%$ of loans had CLTVs under $95 \%$. If anything, the distribution of CLTVs shifts to the left in 2006, meaning that CLTVs became less aggressive. For example, the share of people putting at least $20 \%$ down increases from $41 \%$ of borrowers to $48 \%$ in 2006 .

In order to show the evolution of CLTVs for all years in the sample, we calculate the mean CLTV of purchase mortgages made in a given year along with the 5th, 25th, 75th, and 95th 
percentile CLTV. Figure 2 plots these five statistics every year between 1996 and 2015 and illustrates the same steady distribution of CLTVs shown in the Figure 1 over the entire time series. During this same period, house prices experienced a large run-up (up to 2005) and subsequent collapse and recovery. Even while "V" and the frequency of new purchases originations were changing dramatically over the time series (see Figure A3), the dollars of mortgage debt per dollar of housing collateral being used to finance purchases was very steady. Importantly, it is not the case that the mean stayed the same while the tails of the distribution moved around. Specifically, what we do not see is a distribution where the 75 th and 95 th percentiles of the distribution increased during the bubble. We obtain a very similar picture when we value-weight each loan (Figure A4). There is an increase in the 75 th percentile in 2006 to $100 \%$ CLTV that is a reflection of the "discreteness" of percentiles. Figure 1 shows that the CLTV distributions do not move in any significant way.

\subsection{Government-guaranteed vs. private high-CLTV loans}

The steadiness of CLTV ratios is perhaps unexpected given the documented increase in origination of private-sector mortgages with very low down payments during the housing boom. This increase can be clearly seen in Panel A of Figure 3. The share of private-sector loans with CLTVs $\geq 95 \%$ increases from less than ten percent of all origination to nearly thirty percent of all purchase loans at the height of the housing boom in 2006. How can the share of such high CLTV mortgages have increased so dramatically with no contemporaneous increase in the distribution of CLTVs? The answer becomes clear in Panel B of the same Figure.

Panel B plots the share of all purchase loans guaranteed by the FHA and the VA that also had CLTVs $\geq 95 \%$. What this figure shows is that the share of all loans (both government guaranteed and private-sector) with CLTVs $\geq 95 \%$ hardly budged during the housing boom. And the steadiness of the CLTVs documented in Figure 2 becomes clear in light of this fact.

Figure A5 provides another look at the role of government guaranteed loans in the mort- 
gage market. To create this figure we classified loans into one of five types. FHA- and VA-guaranteed loans with CLTV either below $95 \%$ or not, and then all other loans. The key takeaways from this figure are twofold. First, as seen in Panel B of Figure 3, the share of loans guaranteed by FHA or VA dropped from $25 \%$ before the boom to about $5 \%$ during the boom and then up to nearly $50 \%$ of all purchase loans in 2010 . The second takeaway is that almost all of the loans guaranteed by these two programs are very high CLTV loans. In no year are fewer than $90 \%$ of FHA- and VA- insured loans mortgages with CLTVs of at least $95 \%$.

\section{Geographic Distribution of High-CLTV Loans}

Section 3.1 shows that the share of purchase loans with high CLTV ratios did not change over the time series, nor did the overall distribution of CLTVs. Despite wildly changing house prices and dramatic shifts in purchase and mortgage origination activity, the debt capacity of housing did not change. What did change was the share of high-CLTV loans explicitly guaranteed by the government through the FHA and VA programs. This section of the paper asks an important follow-up question: were the high-CLTV loans guaranteed by the government before the boom and displaced by the private-sector in the boom going to the same types of borrowers? Or does the steadiness of the CLTV distribution mask shifts in where and to whom the high-CLTV loans were going?

\subsection{Steady high-CLTV utilization within geographies}

Panel A of Figure 4 plots ZIP codes with at least five purchase transactions with mortgages in both 1999 and 2006. The figure shows a positive relationship between the share of loans that were in 1999 guaranteed by either the FHA or the VA and the increase between 2006 and 1999 of the share of private-sector high-CLTV loans. The correlation between these two variables is .464 and demonstrates that, within 5-digit ZIP codes, knowing the importance of 
government-guaranteed loans in the mortgage market is strongly predictive of the share of the 2006 cohort of purchase loans that will be private-sector high-CLTV loans. This result helps to rule out the possibility that the steadiness of the CLTV distribution is masking shifts in the geographic distribution of high-CLTV loans. For example, it could have been that high-CLTV, government-guaranteed loans were going to some parts of the country in 1999 (ZIP codes not in the sand states of AZ, CA, FL, and NV) and then, during the boom, the private-sector's high-CLTV loans were all made to borrowers buying homes in the sand states. But this is not consistent with the results in Panel A of Figure 4.

Panel B of the figure moves along the time series and plots an analogous scatter plot comparing the increase in share of purchase loans insured by the FHA or the VA during the recovery to the share of loans that were in 2006 high-CLTV, private-sector mortgages. As before, we document a strong correlation consistent with the idea that ZIP codes are switching their source of high-CLTV loans from the government, to the private sector, and then back to the government.

We next use publicly available IRS data from 1998 to divide ZIP codes into ten populationweighted deciles of adjusted gross income.

To create Figure 5, we compute the share of purchase loans in each income decile that are FHA/VA and private, high-CLTV. We compute these shares at three different points in time: pre-boom (1999), boom (2006), and post-boom (2013). There are three key takeaways from this figure. First, there is a downward trend in the use of high-CLTV mortgages as income increase. Second, this downward trend stays roughly the same over the whole time series. That is, within each income decile over time, the share of purchase loans that are high-CLTV remains similar. Third, in contrast to the smoothness of the first two takeaways, within each income decile over time the share of high-CLTV loans that are government guaranteed goes from almost all of them, to almost none of them, and then back to almost all of them.

Rather than dividing ZIP codes by income, we next split the country's ZIP codes into 
ten deciles based on house price growth between June of 2002 and June of 2006. In Figure A6, we use the same methodology used to create Figure 2 for the bottom two HP-growth deciles and again for the top top deciles. If CLTVs were steady overall, but higher in highHP growth areas and lower in low-HP growth areas, this figure would reveal this pattern. We find this is not the case. In both cases, the distributions are very steady.

Finally, we split the United States into recourse states and non-recourse states. Figure A7 again shows a steady-CLTV picture within both recourse and non-recourse states. This suggests that the dynamics of collateral rates were not very affected by creditors' ability to pursue legal action against defaulting borrowers.

\subsection{Property characteristics by loan type}

Despite the results above, it is possible that the quality of the collateral backing FHA and private loans could be very different, so that different loans were used to purchase different types of properties. In this section, we look at two characteristics - home age and home size - of all properties traded over the time series. For two samples, the sample of homes purchased using FHA-guaranteed loans and the sample of homes purchased using private, high-CLTV loans, we calculate the distribution of age and square footage. We plot these distributions in Figure 6 demeaned at the ZIP-by-year level. We find that the characteristics of homes financed using high-CLTV loans was similar over the time series, inconsistent with a world where the provision of CLTV-credit changed dramatically during the boom. One exception is that homes financed with FHA-guaranteed loans became relatively larger during the recovery. This makes sense since the private, high-CLTV market all but disappeared and the FHA became the only source of high-LTV loans for all homes, not just small ones.

\subsection{Within-property analysis}

In order to rule out the possibility that unobservable geography-related characteristics might be changing despite the stable CLTVs, we consider a sample of properties that traded 
both pre-boom and during the boom or both during the boom and the recovery period.

Figure A8 shows a repeat-sales index of LTVs constructed using the same methodology employed for measuring house prices over time (see, for example, Case and Shiller (1989)). The figure shows that, within the same properties, changes in LTVs over time vary within a band of 4 percentage points and are, if anything, inversely related to house price movements. We obtain a very similar picture when we include bank-by-county fixed effects rather than property fixed effects, suggesting that even within lenders the patterns are the same (Figure A9).

Next, we employ a different repeat-sales methodology to answer the question of whether switching between private and public sources of high-CLTV loans occurred within properties. Our specification asks what the relationship is between the likelihood a property is purchased with a high-CLTV private-sector loan during the boom if it was financed with a government-guaranteed loan (FHA or VA) when purchased pre-boom. We run regressions of the following form for each property $i$ :

$$
\text { High }-C L T V_{i, 2004-2007}=\text { Govt Guarantee } i, 1996-2003+\eta_{t}+\eta_{t+1}+\eta_{\text {County }}+\varepsilon_{i},
$$

where $\eta_{\text {County }}$ represents county fixed effects to absorb differences across the country in average use of government-guaranteed mortgages, and $\eta_{t}$ and $\eta_{t+1}$ represent year fixed effects for the first and second transactions to absorb overall changes in the rate that borrowers used different types of loans over time.

We present some simple summary statistics in Table 1. We show that, among loans taken out in the period $2004-2007$ for this sample, $24 \%((379,697+193,464) /(2,362,748))$ were private, high-CLTV loans. Of properties financed with FHA/VA loans during the preboom, $33.1 \%$ of them are financed with high-CLTV private loans during the boom, compared to just $21.4 \%$ of properties that were not financed with government-guaranteed loans preboom.

The first column of Table 2 estimates the model in Equation 1 on the more than two 
million properties across the United States that were purchased by one household at some point between 1996 and 2003 (pre-boom) and by a different household between 2004 and 2007 (boom). We restrict the sample to properties where both trades were at arm's length and the buyer financed the purchase with a mortgage.

We find a statistically significant and economically meaningful relationship. A property is 11.4 percentage points more likely to be purchased with a high-CLTV private mortgage if the property was purchased pre-boom with a government-guaranteed loan (comparable to the unconditional results in Table 1.

We run an analogous regression for the crisis and recovery period, focusing on those properties traded first during the boom and then again during the recovery (2008-2015).

$$
\text { Govt Guarantee }_{i, 2008-2015}=H i g h-C L T V_{i, 2004-2007}+\eta_{t}+\eta_{t+1}+\eta_{\text {County }}+\varepsilon_{i}
$$

The results are presented in the second column of Table 2 and are qualitatively very similar to the pre-boom to boom test. In short, even at the property level, we document a striking switching between government-guaranteed, high-CLTV mortgages and high-CLTV mortgages provided by the private-sector. While it can be argued that the ZIP code correlations might not be evidence of switching if the types of houses trading are dramatically different pre- and post-boom compared to during the boom, that same argument struggles to explain the results just presented, where the homes are not different, but, in fact, preciesly the same.

\subsection{High-CLTV loan choice by borrower types}

We next turn to the characteristics of borrowers, including within-household analysis, debtto-income choice and loan delinquency. We start with a subsample of the deeds data within which we can track households as they move. To build this data set, we merge the North Carolina deeds data with the North Carolina voter registration records. The voter rolls data 
includes the address of the registered voter, and, if that voter moves within county, their address is updated in their voter registration record. The results, presented in Table 3 and Table 4, are analogous to those in Table 1 and Table 2 except instead of focusing on properties that transact twice, we use borrowing households that borrowed twice to purchase two different properties.

As with the property switching results, the unconditional results for borrower switching presented in Table 3 tell the same story. Borrowing households that use governmentguarantees for access to high-CLTV loans pre-boom switch to private, high-CLTV loans during the boom. And those households that first purchase during the boom and use high-CLTV, private mortgages switch to government-guaranteed mortgages post-boom. In North Carolina, $15.5 \%$ of households who did not use FHA or VA loans for their pre-boom mortgage used a high-CLTV, private mortgage during the boom compared to $27 \%$ of households who did. Similarly, the rate of use FHA or VA loans during the post-boom was $24.7 \%$ for those borrowers that used high-CLTV, private mortgages for the boom purchase, compared to a smaller $18 \%$ of borrowers that did not.

The sample used to estimate the regressions is small but still produces magnitudes that are both statistically and economically significant. Looking at the first specification in Table 4 we see that borrowers are 11.3 percentage points more likely to use a private-sector loan with a high CLTV if their pre-boom loan was FHA- or VA-guaranteed. 17.1\% $((1,026+282)$ / (7660)) of in-sample purchase mortgages originated in NC during the boom were private, high-CLTV mortgages. So an 11.3 percentage point increase amounts to a $66 \%$ increase from the mean. The model estimating switching in the second half of the time series finds a 6.74 percentage point increase or $34.7 \%^{7}$ increase from the mean.

In Figure 7 we consider how the debt-to-income ratio (DTI) of FHA loans compares to private high-CLTV loans of similar and higher credit scores at the peak of the housing boom (2005-2007). DTI is computed as the share of a household's income that goes toward

\footnotetext{
${ }^{7} .0674 /[(1,686+613) /(11,858)]$
} 
mortgage and mortgage-related expenses (like insurance). Panel A shows that FHA loans have a DTI of around 37\%, measured as payments relative to the mortgage (including FHA insurance premia) as a share of monthly income. Panel B considers borrowers with a credit score below 660 and shows that those borrowers carry higher DTIs of around 39\% to $40 \%$. This is consistent with more aggressive lending standards by subprime lenders, particularly those who specialized in these types of loans. Middle and high credit score borrowers have either equal or lower debt-to-income as FHA loans.

We obtain similar results when we consider the Survey of Consumer Finances data. We focus on recent movers (those who moved in the previous 2 years) and all mortgage-related payments. The results are in Table 5. We find that, on average, FHA loans are associated with lower debt-to-income (measured as mortgage-related payments divided by income), but that this difference becomes smaller and insignificant in the boom. The interest rate between FHA and private, high-CLTV loans is also small and insignificant during the boom. Finally, FHA borrowers are more likely to state that the reason for choosing their loan was that this was the only loan they were able to qualify for although, again, this difference decreases during the boom.

\subsection{Performance of Government-Guaranteed and Private, High-CLTV Loans}

In this section, we investigate the ex-post performance of high-CLTV loans guaranteed by the government versus those provided by the private-sector. If the two two types of mortgages were not being used interchangeably by the same types of borrowers in the same types of places, we would expect to see differential delinquency rates. This is not what we find.

Figure 8 plots the share of loans of each type by origination-year cohort that are at some point 90+ days delinquent within three years of origination. As expected, private-sector loans with CLTVs < 95\% have significantly lower delinquency rates than any loan with a CLTV $\geq 95 \%$. Strikingly, though, is the finding that within cohort the rates of delinquency 
for FHA/VA loans is the same as for private loans with CLTVs $\geq 95 \%$. This remains true when we control for county-by-year fixed effects (Panel B) and county-be-year fixed effects, FICO, interest rate, loan type, and DTI (Panel C). This means that, when we do a comparison of loans made in the same areas and to similar borrowers, the delinquency rates of the two types of loans are very similar.

\section{Loan and Leverage Choice by Optimists and Pessimists}

In this section we consider whether there was a change in how optimists and pessimists sort into high-CLTV loans over the credit cycle. This analysis addresses one of the important mechanisms in Geanakoplos (2010), whereby buyers that value assets more bid up prices when they have access to more leverage. We follow the approach developed by Puri and Robinson (2007) to measure optimism based on self-assessed life expectancy from the Survey of Consumer Finances. After controlling for observable characteristics like age, education, and income, the size and sign of the residual allows us to sort people cross-sectionally into optimistic versus pessimistic types (see also Heimer et al. (2019)). It is important to note that this measure of optimism cannot capture longitudinal variation, i.e., we cannot ask whether the population overall becomes more or less optimistic over time. But the measure does pick up information about an individual's outlook in life, and it correlates with whether people think the economy will do well in the next year, which is something people do not have any control over (Figure A11).

We use this data for two purposes. First, we are interested in whether optimists were significantly more likely to take on high LTV loans during the boom. ${ }^{8}$ Second, we look at changes in LTV, debt-to-income inclusive of all mortgage payments (including mortgage insurance), current interest rate and reason for choosing a loan.

We start by showing that the percentage of optimists taking on high LTV loans in the

\footnotetext{
${ }^{8}$ Our focus is on the time series of LTV choice by pessimists and optimists. (Bailey et al., 2019) consider LTV choice in the cross-section by these two groups using social network data from Facebook.
} 
pre-period versus the boom did not change significantly (Figure A12). The highest two quintiles of optimism together make $45 \%$ of the high LTV loan prior to the boom and stay at 47\% during the height of the boom. A similar picture emerges when looking at low LTV loans, again we do not see a strong dislocation of high-CLTV credit towards more optimistic borrowers.

In Figure 9 we break out the presence of optimists versus pessimists among FHA and private high-CLTV loans. Interestingly, we find that optimists maintained stable proportions among these two types of loans. In Figure A13 of the Online Appendix we show that the choice of high-LTV loans is more frequent for optimists across all income quintiles when we do a two-way split by optimism and income quintiles both in the pre period and in the boom.

\section{Changes in the Share of Private, High-CLTV Loans and House Price Increases}

One question that our results raise is whether the changes in the source of high-CLTV loans are merely correlated with the house price cycle, or if there is a causal link between the two. While we cannot provide a definitive answer to this question, one natural approach is to ask which comes first - the change in house prices or the switch from FHA/VA to private sources for high-CLTV loans. We show the results of this analysis in Figure 10 and Table 6. In both cases we find that the increase in house prices during the housing boom precedes the large increase in private high leverage lending rather than the reverse.

Figure 10 sorts ZIP codes into deciles based on the house price growth between 2002 and 2006 and plots both house price growth and the change in private high-CLTV share at the ZIP code level. The three panels split the time period of 1999-2006 into three subperiods

(the first four years and then 2003-2004 and 2005-2006). The figure shows clearly that changes in house prices were higher for the top deciles both in the beginning of the period 
and in the middle, whereas the changes in private high-CLTV share only sort on house prices strongly at the end of the period. While it is, of course, possible that prices rose in anticipation of looser credit, this simple analysis suggests that it is more likely that higher prices were, instead, the reason behind the reduction in FHA-VA share and the increase in the private high-CLTV segment (possibly because these allowed borrowers to participate in "hotter" markets). These results are consistent with Ferreira and Gyourko (2011) who show that increases in subprime lending happen after prices start rising more significantly in most neighborhoods in the U.S.

In Table 6 we use the same instrument developed in Palmer (2015) and Guren et al. (2018) to generate a cross-section of commuting zones (CZ) in the U.S. by their propensity to exhibit large house price movements. Panel A shows that the instrument is highly predictive of house prices. In Panels $\mathrm{B}$ and $\mathrm{C}$ we look at how the instrument sorts CZs based on changes in the FHA-VA share and changes in private high-CLTV loans. As in the previous analysis, we see that the increase in private high-leverage loans is only related to the places with larger price movements at the peak of the boom and not before. This suggests that it is unlikely that the switch to high CLTV-private loans was causally responsible for the higher prices. Instead it appears that they were the results of increasing house prices.

\section{Changes in the Distribution of Lenders}

We also ask whether the types of lenders that provide either FHA/VA loans or private highCLTV loans were previously not available in certain neighborhoods and thus the choice of which type of mortgage to take was constrained across borrowers. We therefore investigate if the composition of mortgage lenders that were available changed within neighborhoods. For this purposes we use data on the loans made by individual lenders from Corelogic. The sample is restricted to the largest lenders in the CoreLogic database, those that originated at least 1000 purchase mortgages during our time period. These leaves us with approximately 
3,000 lenders that made just over $90 \%$ of all loans.

In Panel A of Table 7, we calculate, for each lender-year, the share of their mortgage originations that were FHA- or VA- insured. We then tabulate the share of FHA/VA loans over time, made by lenders that were high or low intensity provides of high-LTV loans. We see that across the board mortgage lenders significantly reduced their reliance on FHA loans, which is in line with our prior findings. For example the median lender went from 9.1\% FHA loans to under $2 \%$. This is even more dramatic for lenders that were more focused on FHA lending before. For example, lenders at the 75th percentage went from 37\% FHA loans to under 15\%. In Panel B we then calculate the share of loans provided by these lenders that were high-CLTV. Say the median lender's new high-CLTV originations were $25 \%$ in 2001 and $30.7 \%$. The time series is similarly stable for other levels of high-CLTV lenders. The results suggest that a majority of the switch from FHA to private high-CLTV mortgages happened within existing lenders. In other words, private high-CLTV loans were not a function of new lenders entering different markets. Instead borrowers had a choice between these loans from the same banks all along.

\section{Conclusion}

This paper shows that the distribution of CLTVs ratios for purchase mortgages has been unchanged in the U.S. for the last two decades. Even during the height of the housing boom of the 2000s the CLTV distribution in the U.S. did not become more skewed towards highly levered loans. The reason for this stability is that a significant fraction of households already had access to loans with very high CLTV levels prior to the boom via directly government guaranteed mortgages such as FHA and VA programs. We show that the increase in privatesector high-CLTV loans almost one for one replaced the share of FHA and VA loans. After

the 2008 crisis, when privately securitized credit dried up again, we see FHA/VA loans go back up and become a significant share of the market. In addition, this shift from directly 
government backed high-CLTV loans to privately securitized loans follows house price increases at the ZIP code level but does not lead them. These findings fit the predictions of the collateral channel that empirical models of the housing market will be broadly accurate in assuming relatively stable collateral ratios, as is the case in Kiyotaki and Moore (1997)). In contrast, the leverage channel-Geanakoplos (2010)—is muted in the US since borrowers can access very high CLTV loans through directly government guaranteed mortgage programs.

However the exact nature in which loans are guaranteed may be important in understanding how the slow down in house prices affected financial markets and ultimately the economy. On the one hand, double trigger models of default explicitly consider separately the roles of debt overhang and ability to pay as triggers of mortgage defaults (see Foote and Willen (2018) for a review of this literature and Mayer et al. (2009) for a more real-time analysis). In addition, the fact that high-CLTV loans went from being explicitly guaranteed by the government during some periods (through FHA/VA insurance) and then became privately securitized may have implications for the types of risks that the mortgage markets originates and the overall financial stability. Private securitization might create misaligned incentives to underwrite risky mortgages, especially if participants expect implicit government guarantees through too-big-to-fail or other government backstops. 


\section{References}

Adelino, M., Schoar, A., And Severino, F. 2016. Loan originations and defaults in the mortgage crisis: The role of the middle class. The Review of Financial Studies 29(7):16351670.

Adelino, M., Schoar, A., And Severino, F. 2017. Dynamics of housing debt in the recent boom and bust. NBER Macroeconomics Annual 32:261-311.

Adelino, M., Schoar, A., And Severino, F. 2018. The role of housing and mortgage markets in the financial crisis. Annual Review of Financial Economics 10:25-41.

AGARWAL, S., BEN-DAVID, I., AND YAO, V. 2015. Collateral valuation and borrower financial constraints: Evidence from the residential real estate market. Management Science $61: 2220-2240$.

Albanesi, S., De Giorgi, G., AND Nosal, J. 2019. Credit growth and the financial crisis: A new narrative. Working paper.

Aragon, D., Caplin, A., Chopra, S., Leahy, J. V., LeCun, Y., Scoffier, M., AND TRACY, J. 2010. Reassessing FHA risk. Nber working paper.

Bailey, M., Dávila, E., Kuchler, T., and Stroebel, J. 2019. House price beliefs and mortgage leverage choice. The Review of Economic Studies 86:2403-2452.

Bernanke, B. ANd Gertler, M. 1989. Agency costs, net worth, and business fluctuations. The American Economic Review 79:14-31.

Bernanke, B., Gertler, M., And Gilchrist, S. 1999. The financial accelerator in a quantitative business cycle framework. Handbook of Macroeconomics 1:1341-1393.

Bernstein, A. 2018. Negative equity, household debt overhang, and labor supply. Working paper.

CAMPBEll, J. Y. AND CocCO, J. F. 2007. How do house prices affect consumption? evidence from micro data. Journal of monetary Economics 54:591-621.

CASE, K. E. AND SHILler, R. J. 1989. The efficiency of the market for single-family homes. The American Economic Review pp. 125-137.

Corbae, D. AND Quintin, E. 2015. Leverage and the foreclosure crisis. Journal of Political Economy 123:1-65.

DEMYANYK, Y. AND VAN HEMERT, O. 2009. Understanding the subprime mortgage crisis. The Review of Financial Studies 24:1848-1880.

Favilukis, J., Ludvigson, S. C., And Van Nieuwerburgh, S. 2017. The macroeconomic effects of housing wealth, housing finance, and limited risk sharing in general equilibrium. Journal of Political Economy 125:140-223. 
FERreira, F. AND GYOURKO, J. 2011. Anatomy of the beginning of the housing boom: Us neighborhoods and metropolitan areas, 1993-2009. Technical report, National Bureau of Economic Research.

Ferreira, F. AND Gyourko, J. 2015. A new look at the us foreclosure crisis: Panel data evidence of prime and subprime borrowers from 1997 to 2012 . Working paper.

Foote, C. L. AND Willen, P. S. 2018. Mortgage-default research and the recent foreclosure crisis. Annual Review of Financial Economics 10:59-100.

GeAnAKOPlOS, J. 1997. Promises, promises. The economy as an evolving complex system II 27:285.

Geanakoplos, J. 2010. The leverage cycle. NBER Macroeconomics Annual 24:1-66.

Gerardi, K., Lehnert, A., Sherlund, S. M., And Willen, P. 2008. Making sense of the subprime crisis. Brookings Papers on Economic Activity 2008:69-159.

Glaeser, E. L., Gottlieb, J. D., And Gyourko, J. 2012. Can cheap credit explain the housing boom?, pp. 301-359. In Housing and the financial crisis. University of Chicago Press.

GREENWALD, D. 2018. The mortgage credit channel of macroeconomic transmission. Working paper.

Greenwood, R., Hanson, S. G., Shleifer, A., And Sørensen, J. A. 2020. Predictable financial crises. Technical report, Harvard Business School Working Paper.

GUERRIERI, V. AND UHLIG, H. 2016. Housing and credit markets: booms and busts, pp. 1427-1496. In Handbook of Macroeconomics, volume 2. Elsevier.

Guren, A. M., MCKay, A., Nakamura, E., And Steinsson, J. 2018. Housing wealth effects: The long view. Technical report, National Bureau of Economic Research.

Heimer, R. Z., Myrseth, K. O. R., And Schoenle, R. S. 2019. Yolo: Mortality beliefs and household finance puzzles. The Journal of Finance 74:2957-2996.

Justiniano, A., Primiceri, G. E., And Tambalotti, A. 2015. Household leveraging and deleveraging. Review of Economic Dynamics 18:3-20.

Justiniano, A., Primiceri, G. E., and Tambalotti, A. 2019. Credit supply and the housing boom. Journal of Political Economy 127:1317-1350.

Keys, B. J., Piskorski, T., Seru, A., And Vig, V. 2012. Mortgage financing in the housing boom and bust, pp. 143-204. In Housing and the Financial Crisis. University of Chicago Press.

Kim, Y. S., Laufer, S. M., Stanton, R., Wallace, N., And Pence, K. 2018. Liquidity crises in the mortgage market. Brookings Papers on Economic Activity 2018:347-428. 
Kiyotaki, N. AND Moore, J. 1997. Credit cycles. Journal of Political Economy 105:211248.

KRIShnamurthy, A. AND MUIR, T. 2017. How credit cycles across a financial crisis. Technical report, National Bureau of Economic Research.

Kruger, S. AND MaturanA, G. Forthcoming. Collateral misreporting in the rmbs market. Management Science .

LACOUR-LitTle, M. 2007. The home purchase mortgage preferences of low-and moderateincome households. Real Estate Economics 35:265-290.

Landvoigt, T., Piazzesi, M., And Schneider, M. 2015. The housing market(s) of san diego. American Economic Review 105:1371-1407.

Mayer, C., Pence, K., And Sherlund, S. M. 2009. The rise in mortgage defaults. Journal of Economic perspectives 23:27-50.

Mian, A., RAO, K., AND SufI, A. 2013. Household balance sheets, consumption, and the economic slump. The Quarterly Journal of Economics 128:1687-1726.

Mian, A. AND Sufi, A. 2011. House prices, home equity-based borrowing, and the us household leverage crisis. American Economic Review 101:2132-56.

Mian, A., Sufi, A., AND VERnER, E. 2017. Household debt and business cycles worldwide. The Quarterly Journal of Economics 132:1755-1817.

PALMER, C. 2015. Why did so many subprime borrowers default during the crisis: Loose credit or plummeting prices? Available at SSRN 2665762 .

Pinto, E. J. 2010. Government housing policies in the lead-up to the financial crisis: A forensic study. Discussion Draft. Washington, DC: American Enterprise Institute.

Puri, M. And Robinson, D. T. 2007. Optimism and economic choice. Journal of financial economics 86:71-99. 


\section{Figure 1: Cumulative Distribution Functions of CLTVs}

This figure shows cumulative distribution of combined loan-to-value ratios in CoreLogic for all loans (Panel A) and for those that are not classified as either FHA or VA (Panel B). This includes Fannie Mae and Freddie Mac, any privately securitized loans, or loans held on the portfolios of private financial institutions.
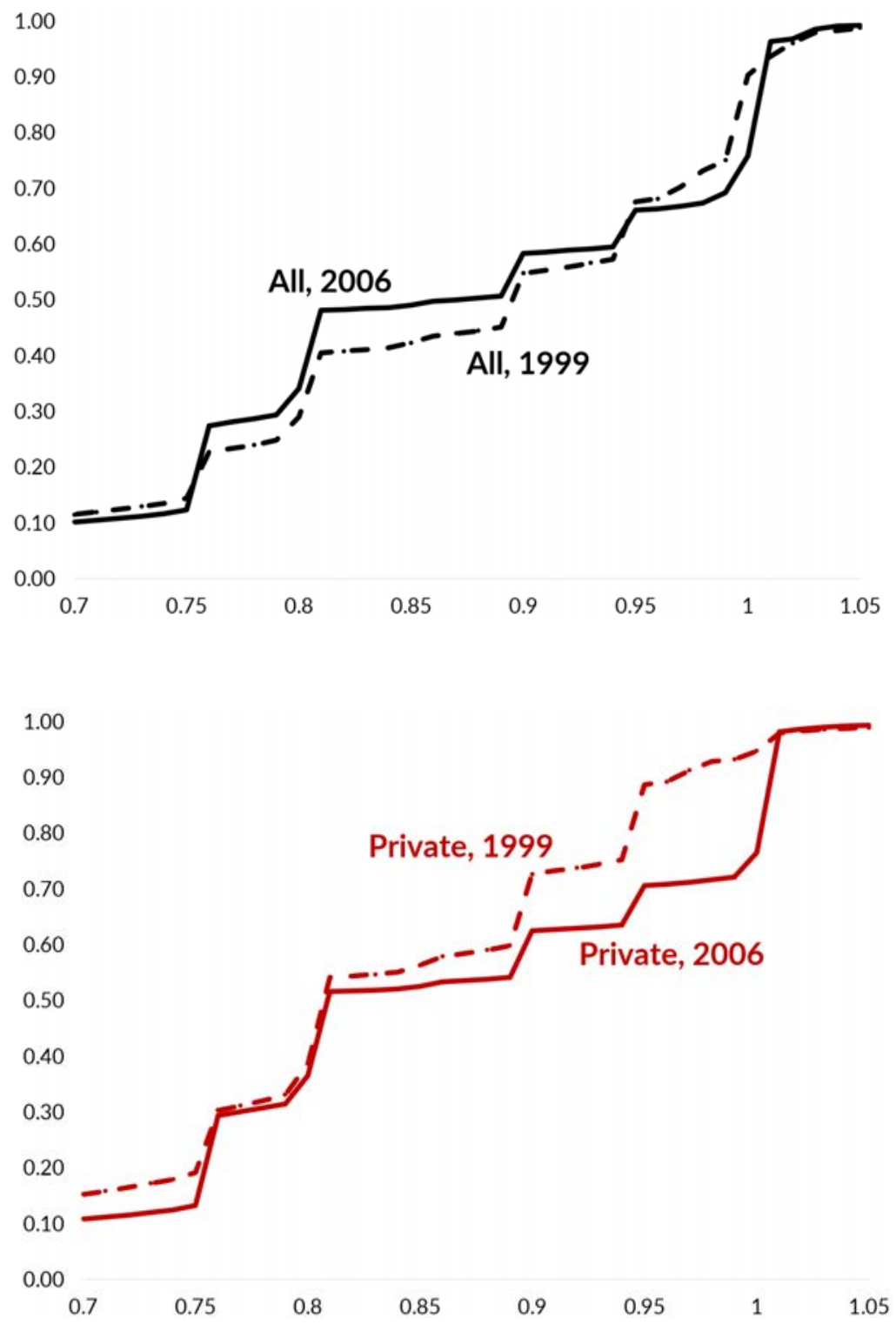


\section{Figure 2: A Steady Distribution of Purchase Loan CLTV Ratios Over Time}

This figure plots the combined loan-to-value ratios (CLTVs) of the universe of purchase transactions financed with at least some debt covered in the CoreLogic deeds data between 1996 and 2015. Each purchase transaction includes data on up to three mortgages, one primary mortgage and up to two piggyback mortgages. The percentiles and mean are calculated using all purchase loans originated in the calendar year.

$110 \%$

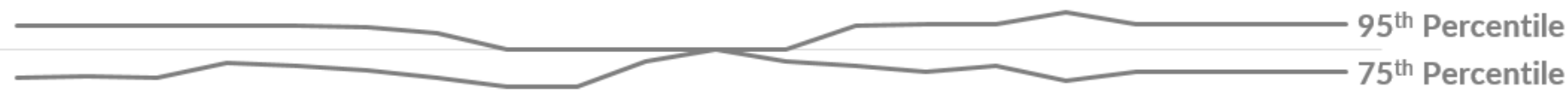

$90 \%$

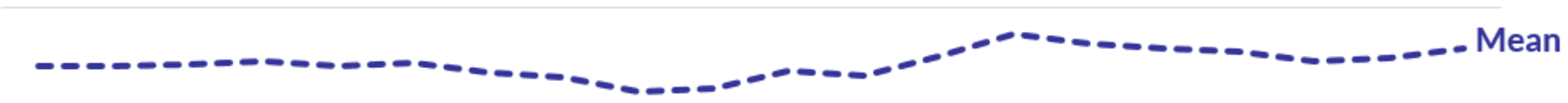

$\stackrel{\infty}{\infty}$

$80 \%$

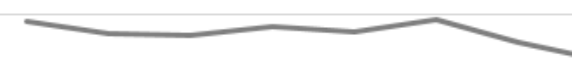

$25^{\text {th }}$ Percentile

$70 \%$

$60 \%$

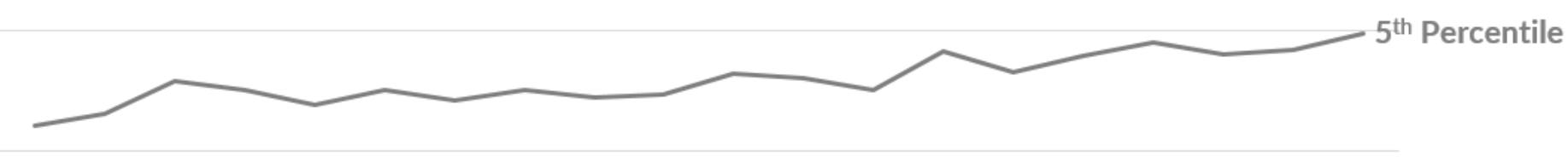

$40 \%$

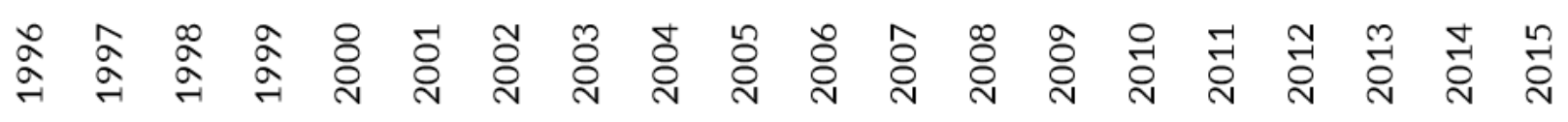




\section{Figure 3: Share of all Purchase Loans by Year}

In this figure purchase loans are grouped into one of four types: FHA- with CLTV $\geq 95 \%$, VA-guaranteed with CLTV $\geq 95 \%$, and all other loans with CLTV $\geq 95 \%$. The top figure plots the share of all purchase loans were not explicitly government guaranteed and had CLTV ratios $\geq 95 \%$. The second plot adds the share of high-CLTV loans explicitly guaranteed by the government.

0.1

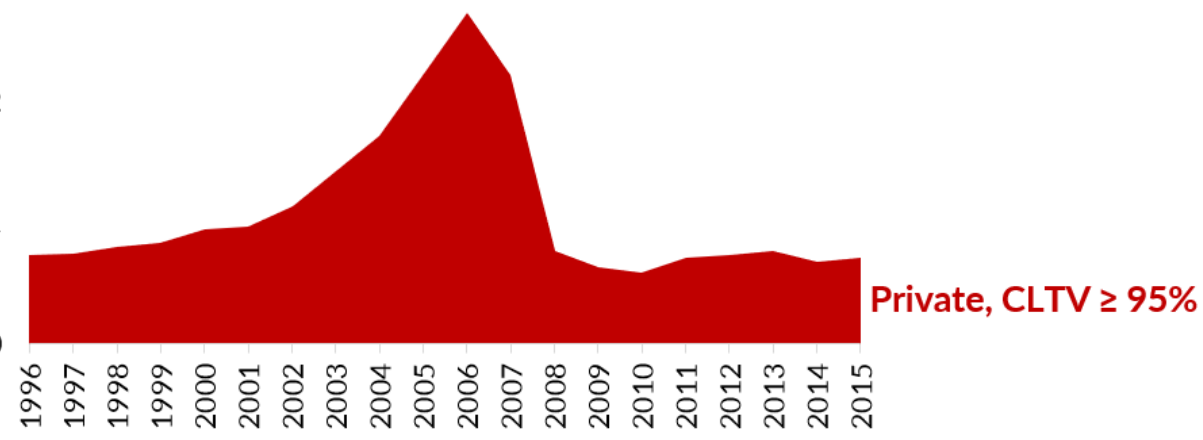

0.6

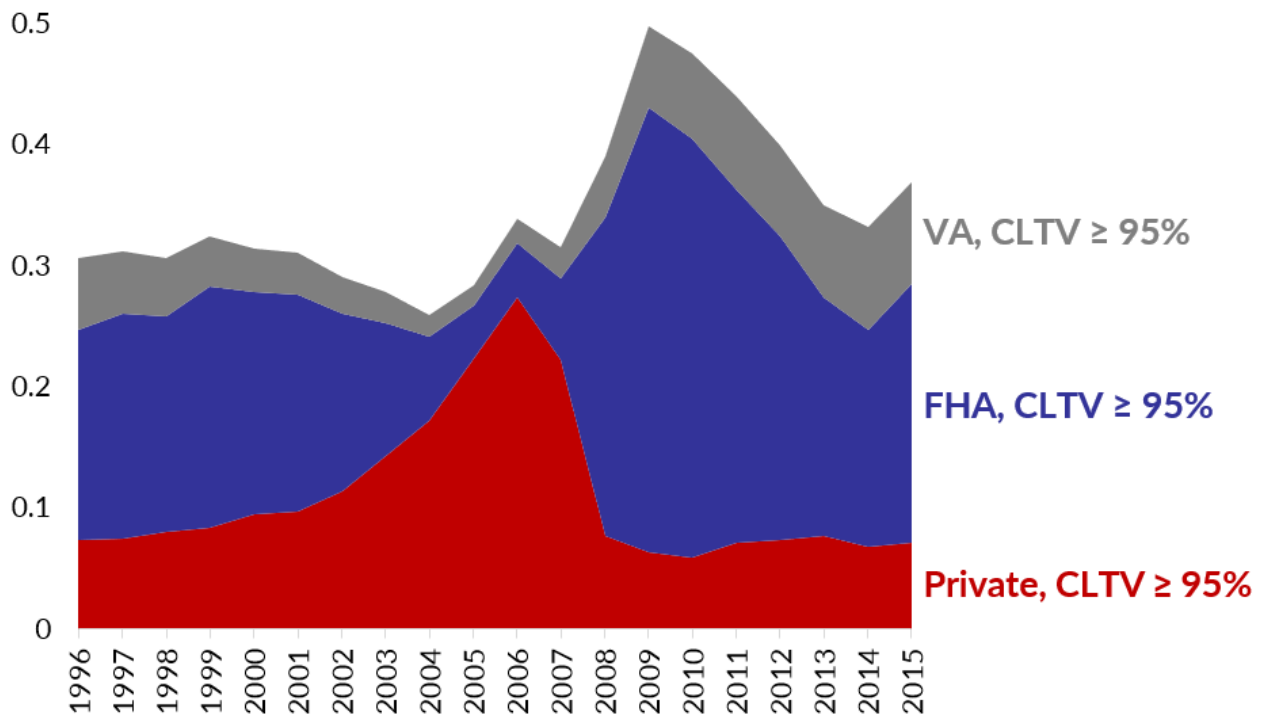




\section{Figure 4: Change in ZIP Code Level Share of Loan Types}

This first panel of this figure plots ZIP codes based on the share of 1999 purchase loans in that ZIP code that were FHA- or VA-guaranteed (on the x-axis) and the difference between the share 2006 purchase loans in that ZIP code that were not FHA or VA and had CLTVs $\geq 95 \%$ and the share of such loans in 1999 (on the $y$-axis). The second panel of this figure plots ZIP codes based on the share of 2006 purchase loans in that ZIP code that were not FHA or VA and had CLTVs $\geq 95 \%$ (on the x-axis) and the difference in the share of 2013 purchase loans guaranteed by either the FHA or VA and the share of such loans in 2006. (on the y-axis).
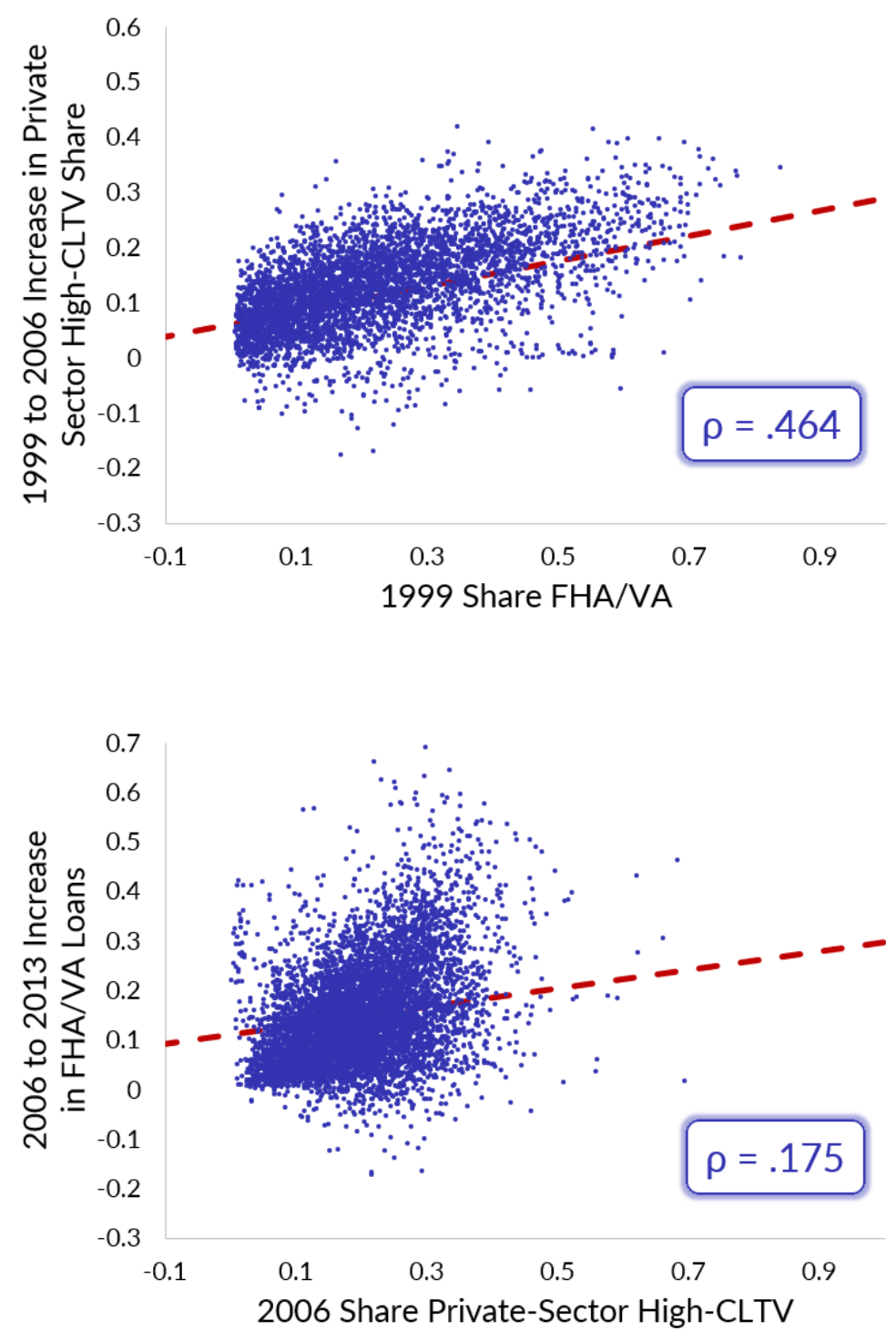


\section{Figure 5: Share Government-Guaranteed and Private Sector across Incomes Deciles over Time}

To produce this graph we created ten deciles of 1998-ZIP code income. Deciles are population weighted such that each decile contains ten percent of the population of the United States. For each year, we calculate the share of purchase loans that are guaranteed by the government and the share that private-sector with CLTVs $\geq 95 \%$. The ZIP-code level income data is from the IRS, https://www.irs.gov/statistics/soi-tax-stats-individual-income-tax-statistics-zip-code-data-soi.
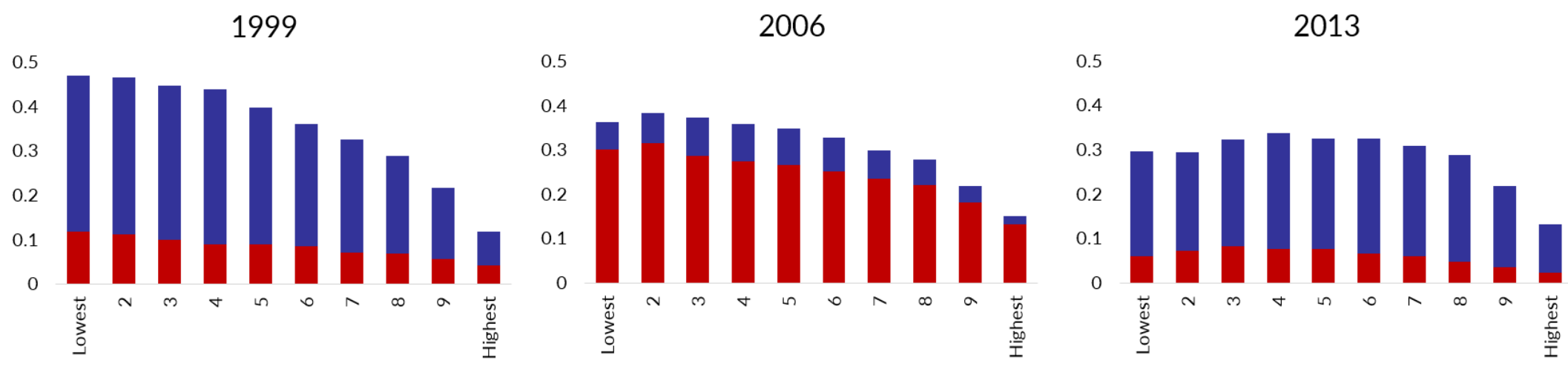

Share of Purchase Loans Guaranteed by FHA/VA Share of Purchase Loans Private, CLTV $\geq 95 \%$ 


\section{Figure 6: Age and Square Footage of Homes Purchased Each Year}

The first figure plots the distribution of home age of homes purchased year by year, the second figure plots square footage. Both variables are de-meaned by the average home age and square footage of homes sold in the same ZIP code-by-year. Included are purchases financed with FHA loans (blue) and homes purchased with non-FHA/VA loans and CLTVs $\geq 95 \%$ (red).

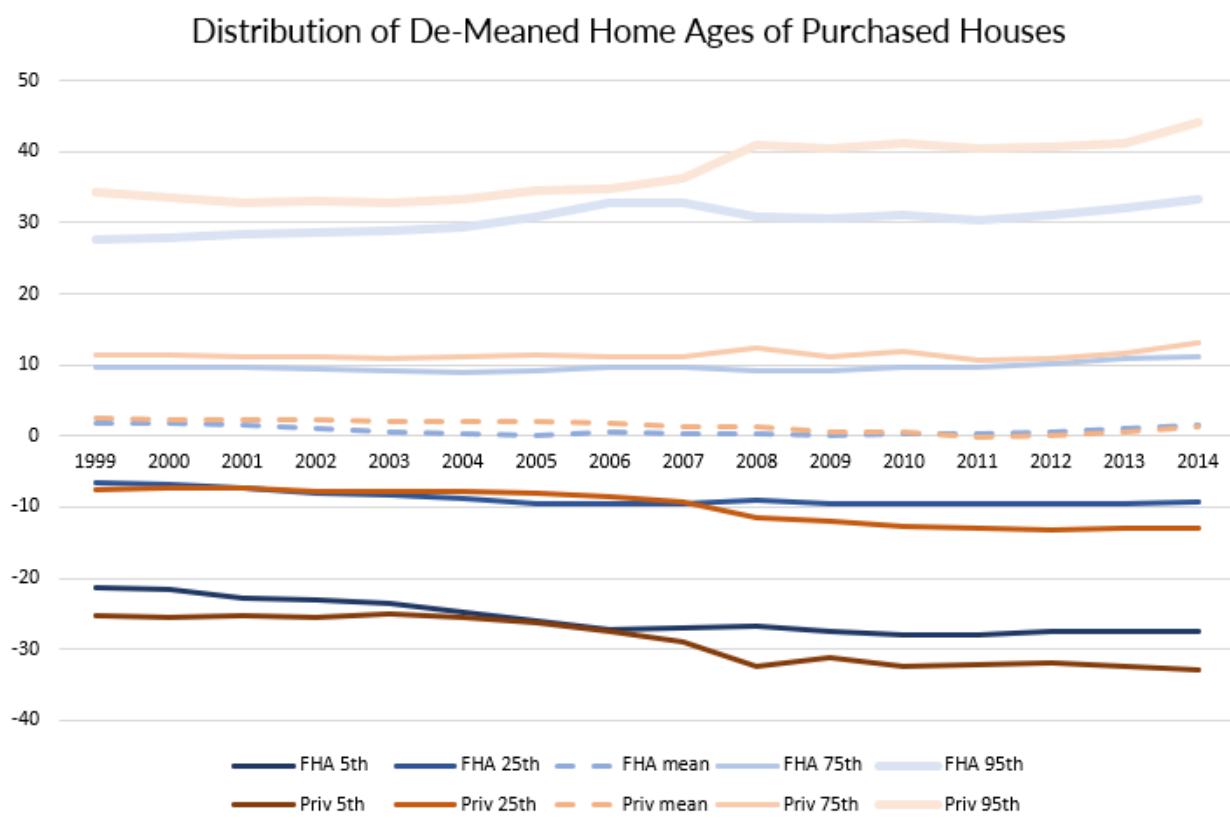

Distribution of De-Meaned Square Feet of Purchased Houses

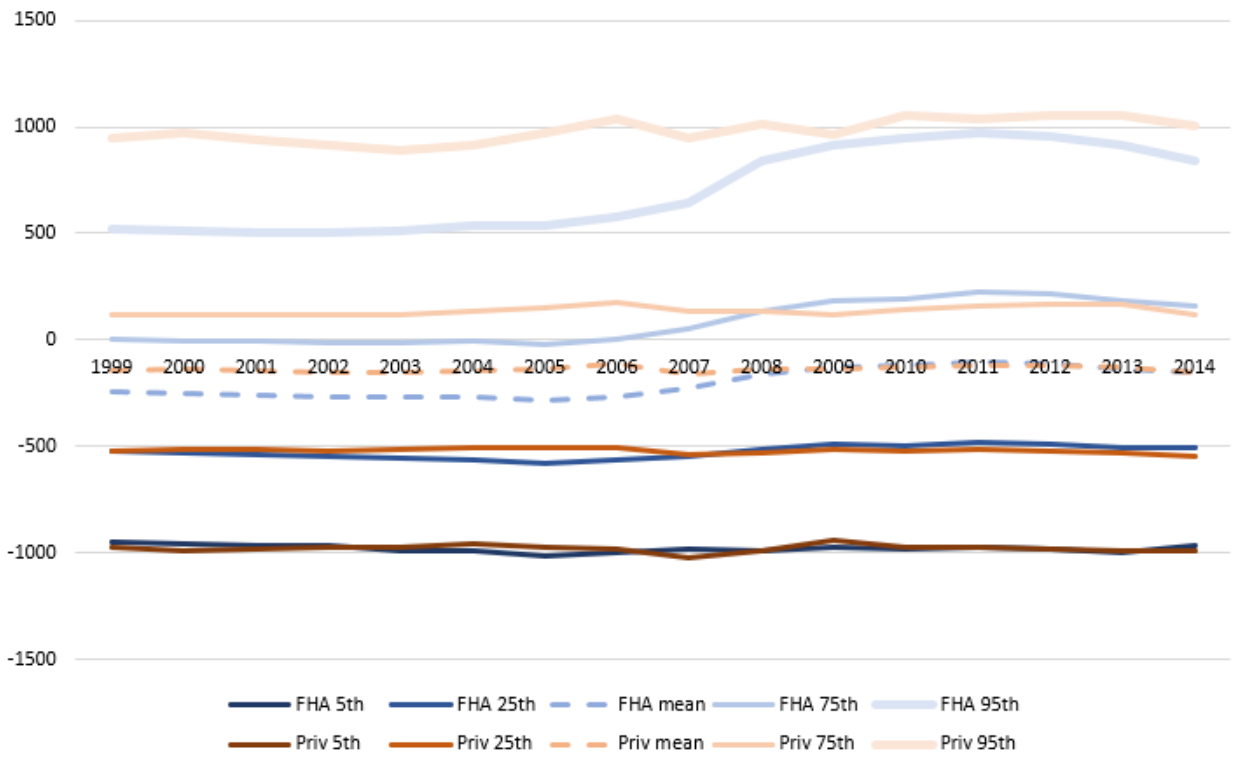




\section{Figure 7: Debt-to-Income by Loan-to-Value, 2005-2007 Originations}

Figure shows point estimates and standard errors for debt-to-income levels regressed on loan-to-value bin indicators. Figure only includes full documentation loans and loans with a combined loan-to-value ratio above 90\%. Data comes from First American LoanPerformance, McDash Analytics.

\section{Panel A: FHA loans}

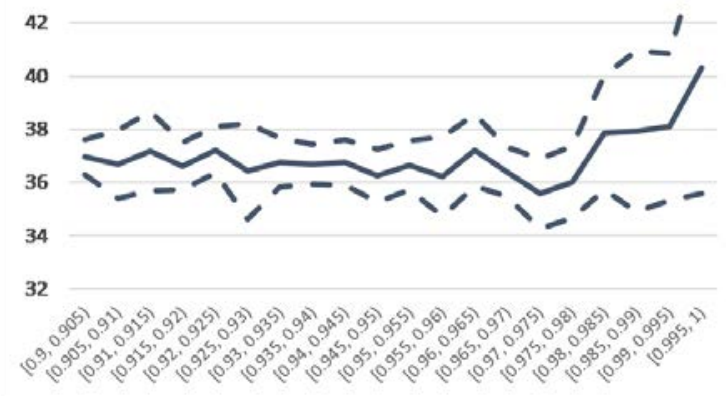

Panel C: Non-FHA loans, $660<$ Credit score $\leq 720$

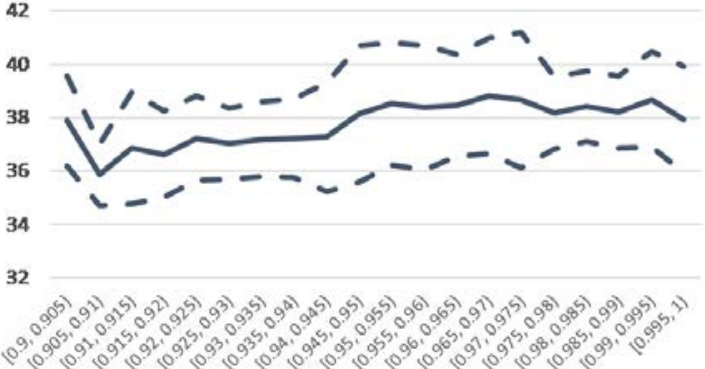

Panel B: Non-FHA loans, Credit score $\leq 660$

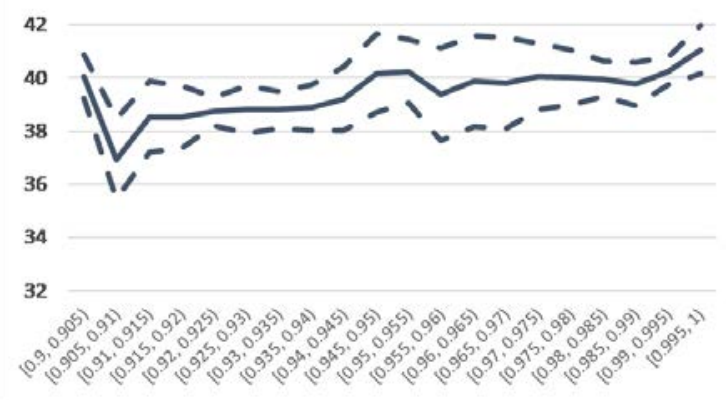

Panel D: Non-FHA loans, Credit score $>720$

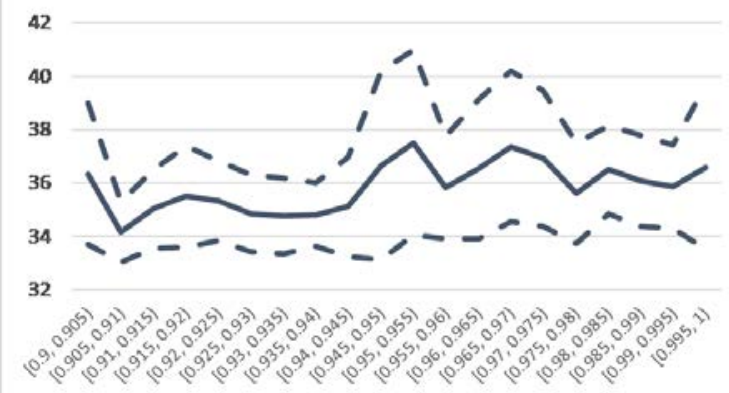




\section{Figure 8: Share 90+ Days Delinquent Within 3 Years of Origination}

These figure uses McDash data starting in the second half of 2005 to plot the delinquency rates of private mortgages relative to those guaranteed by the government. The first figure calculates, year by year, the share of loans originated within each category that were $90+$ days delinquent at some point in the three years after origination. The second figure includes county-by-year fixed effects and plots private-sector mortgage delinquency rates relative to government guaranteed loans' delinquency rates. The third panel further adds controls for credit score, interest rate, loan type, and DTI. Dashed lines indicate $95 \%$ confidence intervals.
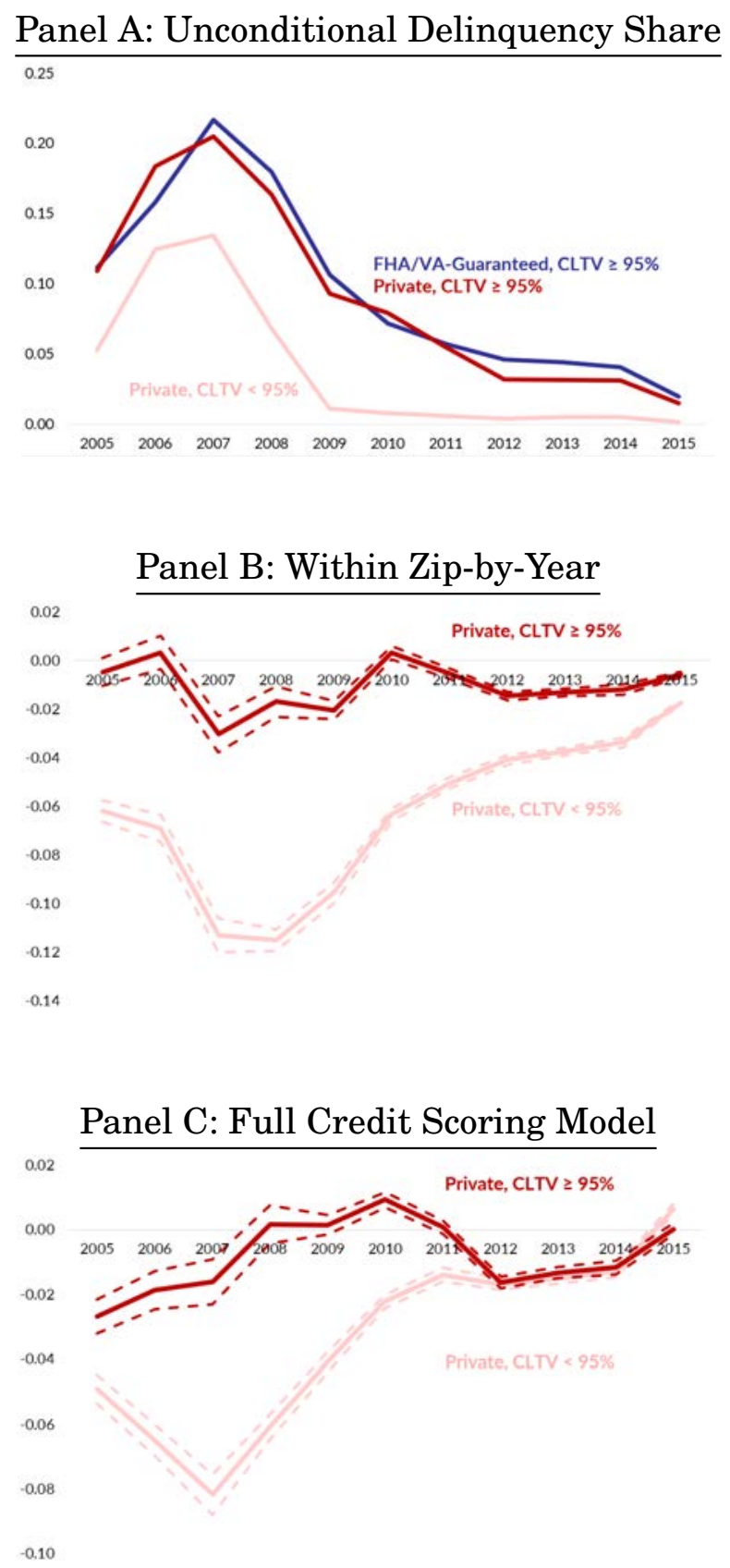


\section{Figure 9: Are Optimists Switching Within High-LTV Loan Types?}

Data is from the Survey of Consumer Finances (SCF). Optimism is measured using as in Puri and Robinson (2007). The pre-period uses SCF waves 1995, 1998, and 2001. The boom period uses SCF waves 2004 and 2007; Bust 2010 wave, and Post 2013 and 2016 waves. High-LTV borrowers are those who report outstanding mortgage balances valued at more than $80 \%$ of the value of their home.

FHA High-LTV Borrowers

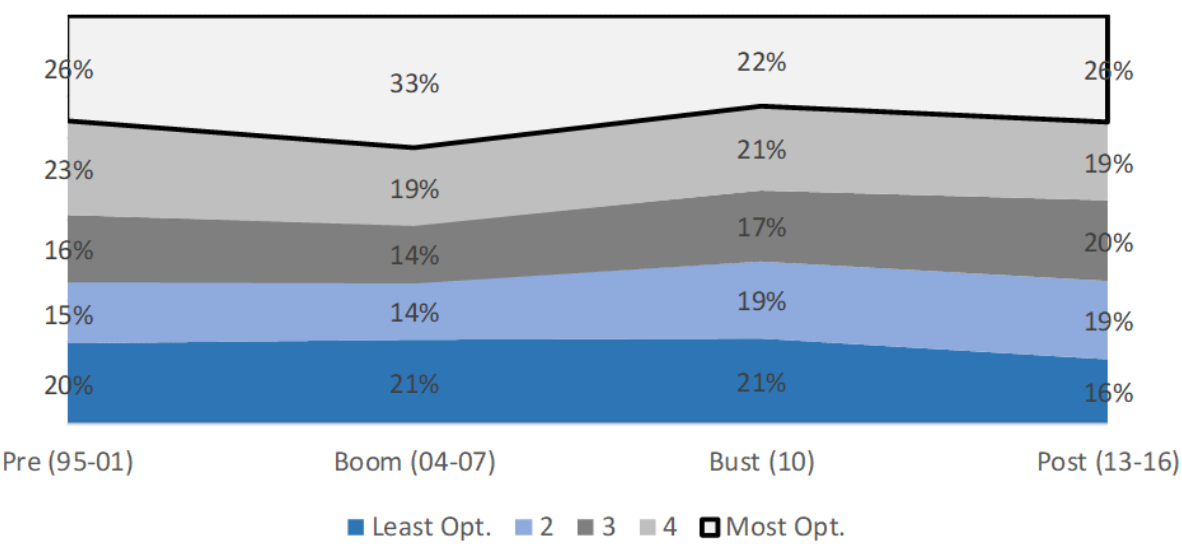

Private, High-LTV Borrowers

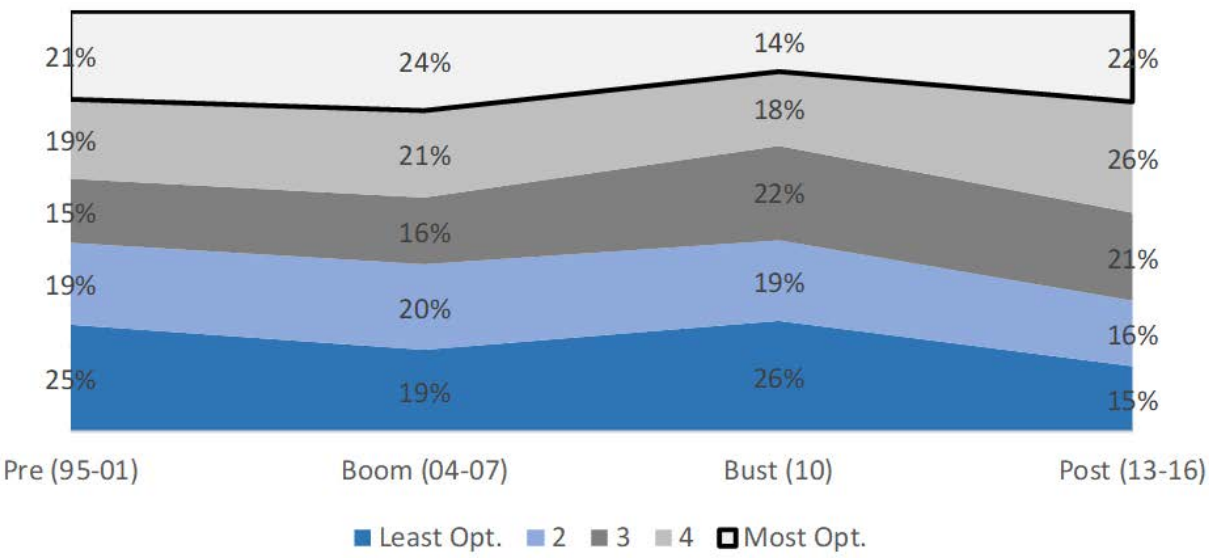


Figure 10: Changes in Private, High-CLTV Share by House Price Change

Figure shows averages of house price changes and the change of high-CLTV purchase loans at the ZIP code level. ZIP codes are grouped into deciles by the change in house prices between 2002 and 2006.
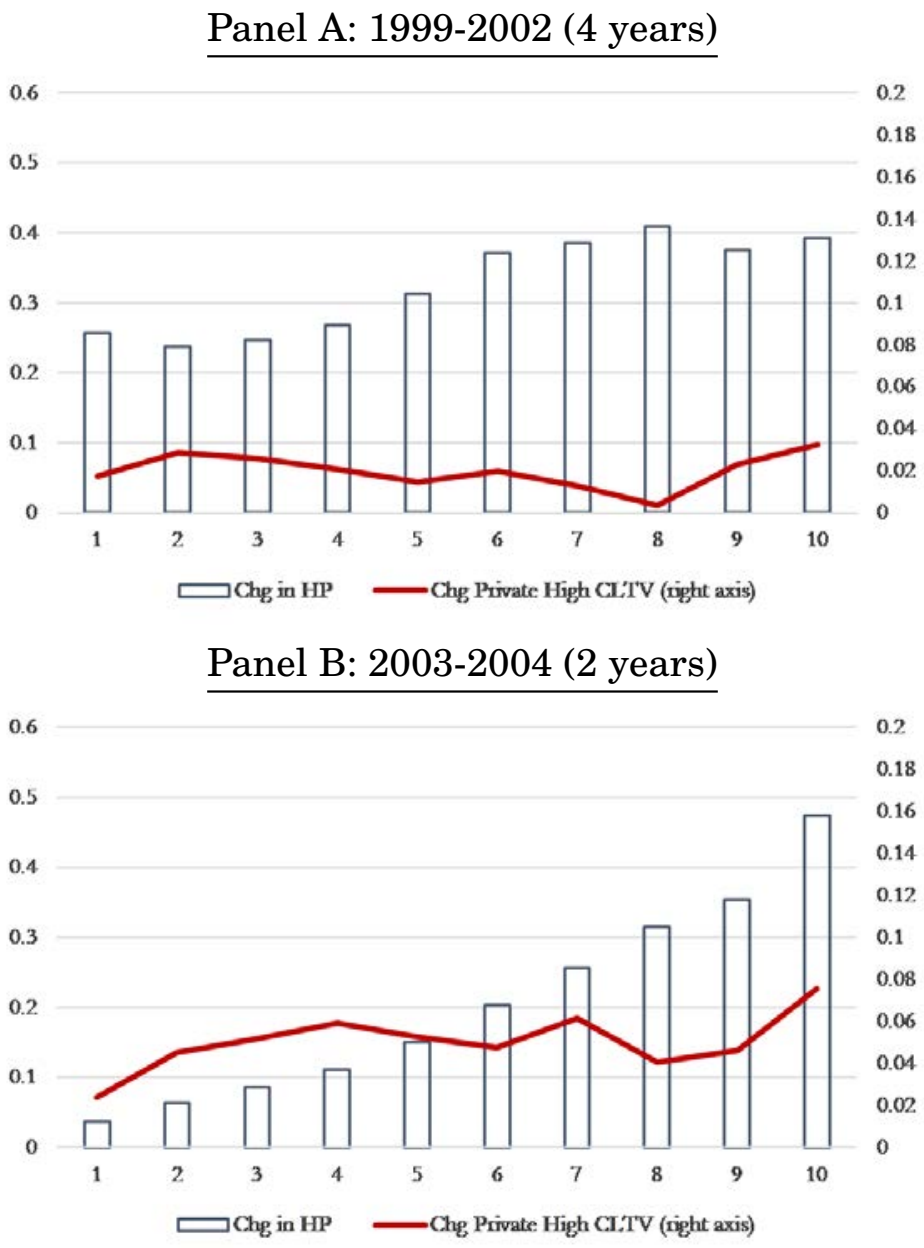

Panel C: 2005-2006 (2 years)

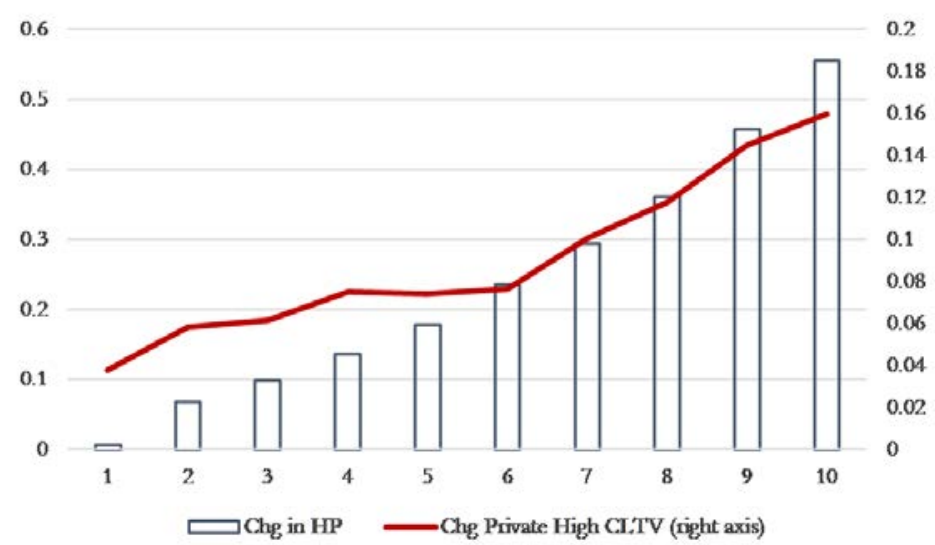




\section{Table 1: Summary Statistics of Properties Transacting Twice}

This table uses CoreLogic data and presents counts and shares by type of mortgage originated in the 1996-2003, 2004-2007, and 2008-2015 periods for those properties that saw exactly one transaction during the boom and exactly one transaction pre-boom (panel A) or post-boom (panel B).

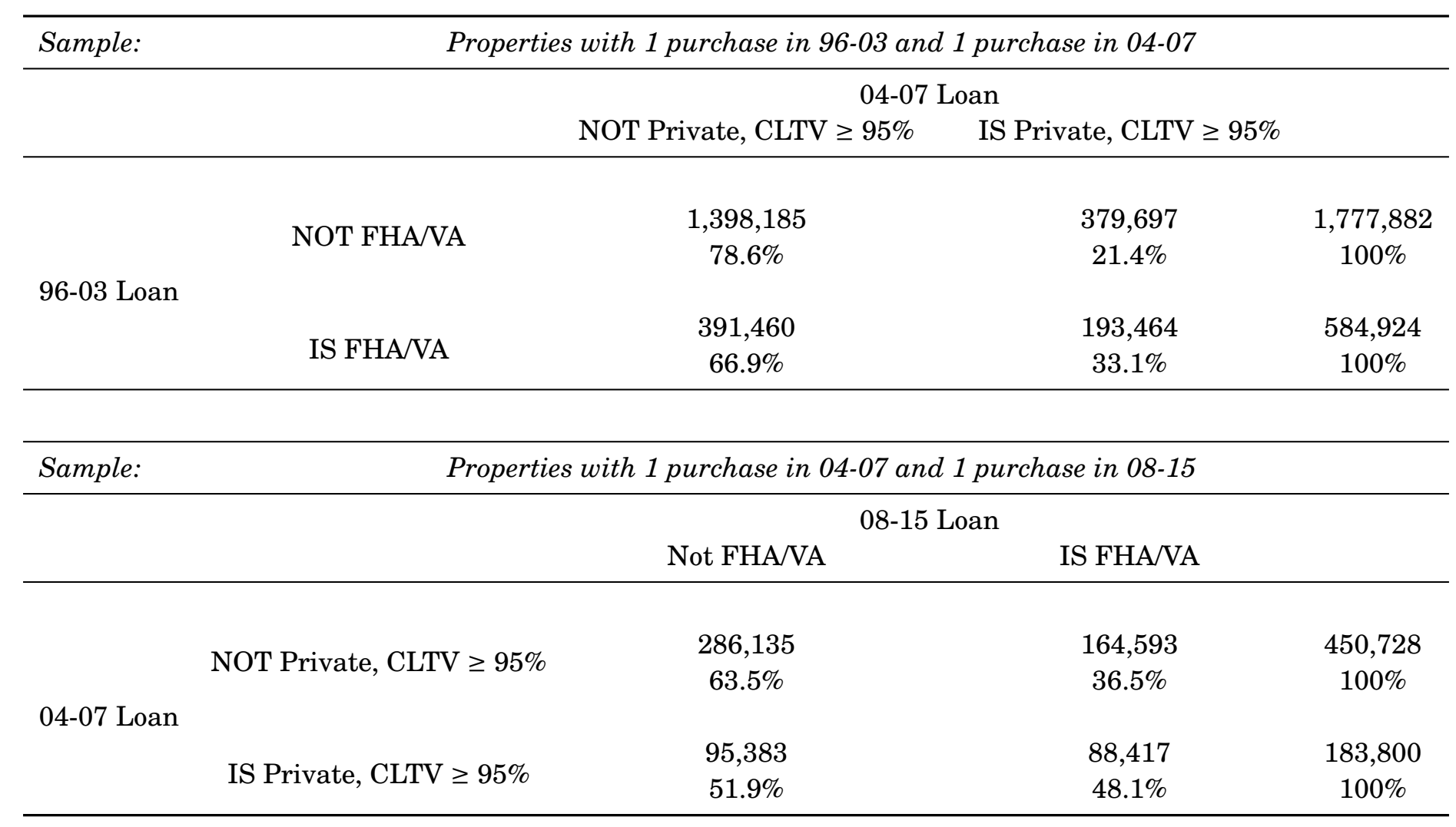


Table 2: Switching between Loan Types (Properties Transacting Twice)

This table uses CoreLogic data. The first sample includes all those properties we observe trade at arms-length exactly one time in the period 1996-2003 and exactly one time in the period 2004-2007. The second sample is analogous for the periods 2004-2007 and 2008-2015. Standard errors clustered at the county level are reported in parentheses. Coefficients significant at the $10 \%, 5 \%$, and $1 \%$ levels are marked with $\mathrm{a} * * *$, and $* * *$, respectively.

\begin{tabular}{|c|c|c|}
\hline Sample: & $\begin{array}{c}\text { Properties with } 1 \text { purchase in 96-03 } \\
\text { and } 1 \text { purchase in 04-07 }\end{array}$ & $\begin{array}{c}\text { Properties with } 1 \text { purchase in } 04-07 \\
\text { and } 1 \text { purchase in } 08-15\end{array}$ \\
\hline Dependent Variable: & 04-07 Loan is Private with CLTV $\geq 95 \%$ & 08-15 Loan is FHA/VA \\
\hline 96-03 Loan FHA or VA & $\begin{array}{c}0.114^{* * *} \\
(0.007)\end{array}$ & \\
\hline 04-07 Loan Private with CLTV $\geq 95 \%$ & & $\begin{array}{l}0.0941^{* * *} \\
(0.006)\end{array}$ \\
\hline \multicolumn{3}{|l|}{ Fixed Effects } \\
\hline County & $\mathrm{Y}$ & $\mathrm{Y}$ \\
\hline Year of First Loan & $\mathrm{Y}$ & $\mathrm{Y}$ \\
\hline Year of Second Loan & $\mathrm{Y}$ & $\mathrm{Y}$ \\
\hline $\mathrm{N}$ & $2,362,748$ & 634,495 \\
\hline $\mathrm{R}$-squared & 0.098 & 0.088 \\
\hline
\end{tabular}


Table 3: Summary Statistics for Households in North Carolina with Two Transactions

This table uses CoreLogic data and voter registration data from North Carolina. The table presents counts and shares of certain types of mortgages originated in the 1996-2003, 2004-2007, and 2008-2015 periods for those households that made exactly one purchase transaction during the boom and exactly one purchase transaction pre-boom (panel A) or post-boom (panel B).

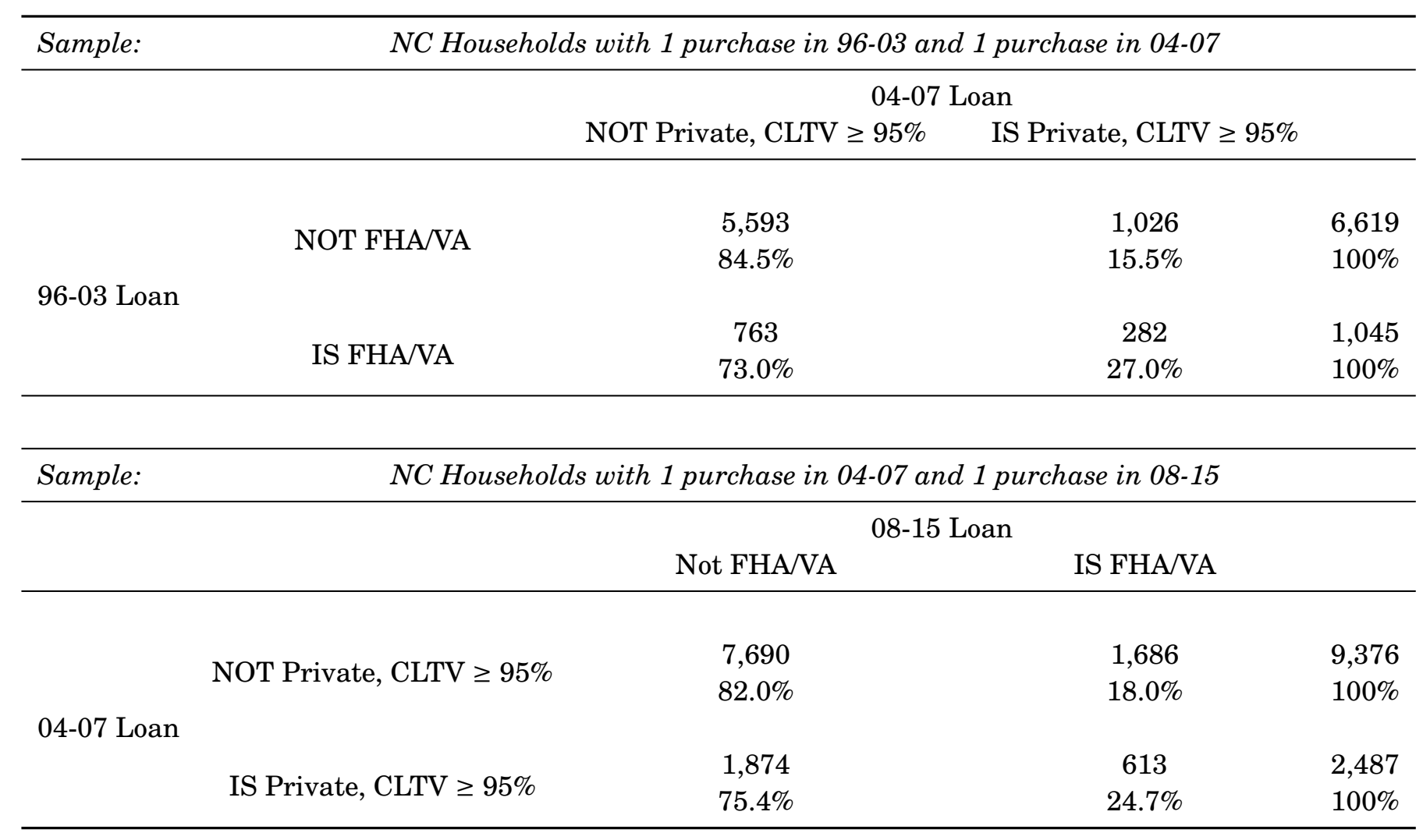


Table 4: Switching Loan Types (Households in North Carolina with Two Transactions)

This table uses CoreLogic and voter registration data from North Carolina. The first sample includes all those households we observe take out exactly one loan in the period 1996-2003 at one property and exactly one loan in the period 2004-2007 at another property in North Carolina. The second sample is analogous for the periods 2004-2007 and 2008-2015. Standard errors clustered at the county level are reported in parentheses. Coefficients significant at the 10\%, 5\%, and 1\% levels are marked with a $* * *$, and ***, respectively.

\begin{tabular}{|c|c|c|}
\hline Sample: & $\begin{array}{l}\text { NC Households with } 1 \text { purchase in 96-03 } \\
\text { and } 1 \text { purchase in 04-07 }\end{array}$ & $\begin{array}{l}\text { NC Households with } 1 \text { purchase in 04-07 } \\
\text { and } 1 \text { purchase in 08-15 }\end{array}$ \\
\hline Dependent Variable: & 04-07 Loan is Private with CLTV $\geq 95 \%$ & 08-15 Loan is FHA/VA \\
\hline 96-03 Loan FHA or VA & $\begin{array}{c}0.113^{* * *} \\
(0.014)\end{array}$ & \\
\hline 04-07 Loan Private with CLTV $\geq 95 \%$ & & $\begin{array}{l}0.0674^{* * *} \\
(0.011)\end{array}$ \\
\hline \multicolumn{3}{|l|}{ Fixed Effects } \\
\hline County & $\mathrm{Y}$ & $\mathrm{Y}$ \\
\hline Year of First Loan & $\mathrm{Y}$ & $\mathrm{Y}$ \\
\hline Year of Second Loan & $\mathrm{Y}$ & $\mathrm{Y}$ \\
\hline $\mathrm{N}$ & 7,660 & 11,858 \\
\hline $\mathrm{R}$-squared & 0.031 & 0.054 \\
\hline
\end{tabular}


Table 5: Characteristics of FHA and private, high-CLTV loans in the Survey of Consumer Finances

Data is from the Survey of Consumer Finances (SCF). Optimism is measured using as in Puri and Robinson (2007). The pre-period uses SCF waves 1995, 1998, and 2001. The boom period uses SCF waves 2004 and 2007; Bust: 2010 wave, and Post: 2013 and 2016 waves. Sample is restricted to borrowers who purchased a home in the previous two years with non-missing LTV and have reported mortgage balances of more than $80 \%$ of the value of their home. Age, race, education level and gender fixed effects included in all regressions. DTI represents all mortgage-related payments by the household scaled by annual income, and "Only qualify" is an indicator variable for whether the household reports choosing the loan or the lender because it was "easier to qualify" or was the only option they qualified for. Standard errors clustered at the age and year level. Coefficients significant at the $10 \%, 5 \%$, and $1 \%$ levels are marked with $\mathrm{a} * * *$, and $* * *$, respectively.

\begin{tabular}{|c|c|c|c|c|}
\hline & LTV & DTI & Interest rate & Only qualify \\
\hline FHA & $\begin{array}{c}0.027^{* * *} * \\
(0.001)\end{array}$ & $\begin{array}{c}-0.010^{* * *} \\
(0.002)\end{array}$ & $\begin{array}{c}-40.6^{* * *} \\
(12.4)\end{array}$ & $\begin{array}{c}0.105^{* *} \\
(0.046)\end{array}$ \\
\hline Boom period & $\begin{array}{c}0.016^{* * *} \\
(0.002)\end{array}$ & $\begin{array}{c}0.046 * \\
(0.025)\end{array}$ & $\begin{array}{c}-170.0 * * * \\
(18.7)\end{array}$ & $\begin{array}{c}-0.014 \\
(0.036)\end{array}$ \\
\hline Crisis period & $\begin{array}{c}0.030 * * * \\
(0.004)\end{array}$ & $\begin{array}{c}0.029 * * * \\
(0.006)\end{array}$ & $\begin{array}{c}-270.0^{* * *} \\
(7.2)\end{array}$ & $\begin{array}{c}-0.064^{* *} \\
(0.032)\end{array}$ \\
\hline Recovery period & $\begin{array}{l}0.018^{*} \\
(0.010)\end{array}$ & $\begin{array}{c}0.008 \\
(0.016)\end{array}$ & $\begin{array}{c}-400.0^{* * * *} \\
(13.5)\end{array}$ & $\begin{array}{l}-0.011 \\
(0.039)\end{array}$ \\
\hline FHA\#Boom & $\begin{array}{c}-0.019 * * \\
(0.008)\end{array}$ & $\begin{array}{c}0.007 \\
(0.012)\end{array}$ & $\begin{array}{c}30.1^{* * *} \\
(8.3)\end{array}$ & $\begin{array}{c}-0.083^{*} \\
(0.050)\end{array}$ \\
\hline FHA\#Crisis & $\begin{array}{c}-0.009 * * * \\
(0.003)\end{array}$ & $\begin{array}{c}0.027^{* * *} * \\
(0.007)\end{array}$ & $\begin{array}{c}42.8^{* * * *} \\
(7.2)\end{array}$ & $\begin{array}{c}-0.023 \\
(0.053)\end{array}$ \\
\hline FHA\#Recovery & $\begin{array}{c}-0.032^{* * * *} \\
(0.010)\end{array}$ & $\begin{array}{c}0.019 * * * \\
(0.003)\end{array}$ & $\begin{array}{c}39.9 * * * \\
(12.6)\end{array}$ & $\begin{array}{c}-0.074 \\
(0.053)\end{array}$ \\
\hline DTI & & & $\begin{array}{c}44.9 \\
(30.8)\end{array}$ & $\begin{array}{c}0.137 \\
(0.118)\end{array}$ \\
\hline LTV & & & $\begin{array}{l}64.6^{*} \\
(33.8)\end{array}$ & $\begin{array}{c}0.204^{* *} \\
(0.083)\end{array}$ \\
\hline Fixed effects & \multicolumn{4}{|c|}{ Age, Race, Education, Gender } \\
\hline $\begin{array}{l}\mathrm{N} \\
\mathrm{r} 2\end{array}$ & $\begin{array}{c}5,130 \\
0.10\end{array}$ & $\begin{array}{c}5,081 \\
0.19\end{array}$ & $\begin{array}{c}5,070 \\
0.64\end{array}$ & $\begin{array}{c}5,081 \\
0.10\end{array}$ \\
\hline
\end{tabular}


Table 6: Changes in HP and Private, High-CLTV Loans on HP Instrument

Table shows regressions by sub-periods (in 2-year intervals) of changes in three outcome variables (shown in panel titles) at the commuting zone level on the gamma instrument in Guren et al. (2018). Heteroscedasticity-robust standard errors and t-statistics shown.

Panel A: Change in HP

\begin{tabular}{lccccc}
\hline Period: & $00-02$ & $02-04$ & $04-06$ & $06-08$ & $08-10$ \\
\hline Gamma & 0.054 & 0.185 & 0.111 & -0.124 & -0.141 \\
& 0.016 & 0.030 & 0.013 & 0.019 & 0.012 \\
& 3.45 & 6.10 & 8.84 & -6.37 & -11.52 \\
\hline $\mathrm{N}$ & 150 & 175 & 229 & 285 & 305 \\
$\mathrm{R}$-squared & 0.11 & 0.43 & 0.21 & 0.32 & 0.44 \\
\hline \hline
\end{tabular}

Panel B: Change in FHA/VA

\begin{tabular}{lccccc}
\hline Period: & $00-02$ & $02-04$ & $04-06$ & $06-08$ & $08-10$ \\
\hline Gamma & -0.147 & -0.152 & -0.169 & 12.508 & -0.173 \\
& 0.024 & 0.032 & 0.042 & 3.387 & 0.022 \\
& -6.10 & -4.78 & -4.00 & 3.69 & -7.77 \\
\hline $\mathrm{N}$ & 149 & 168 & 223 & 281 & 301 \\
R-squared & 0.23 & 0.00 & 0.03 & 0.03 & 0.14 \\
\hline \hline
\end{tabular}

Panel C: Change in Private, high CLTV loans

\begin{tabular}{lccccc}
\hline Period: & $00-02$ & $02-04$ & $04-06$ & $06-08$ & $08-10$ \\
\hline Gamma & 0.026 & 0.101 & 0.433 & -2.302 & 0.029 \\
& 0.049 & 0.065 & 0.076 & 0.714 & 0.045 \\
& 0.53 & 1.54 & 5.72 & -3.23 & 0.65 \\
\hline $\mathrm{N}$ & 149 & 173 & 220 & 270 & 302 \\
R-squared & 0.00 & 0.00 & 0.16 & 0.03 & 0.00 \\
\hline \hline
\end{tabular}




\section{Table 7: Distributions in the Share of Loan Types by Lenders}

This table describes distributions of the fraction of loans that each lender makes in a given year that are of a given type. The sample is restricted to the largest lenders in the CoreLogic database, those that originated at least 1000 purchase mortgages during the time series. These approximately 3,000 lenders made just over $90 \%$ of all loans. To create Panel A, we calculate, for each lender-year, the share of their originations that were FHA- or VAinsured. We then list some important statisitics of that distribution. For example, of the loans originated in 2001 by the median lender, 9.1\% were FHA- or VA-insured. Panel B calculates the share of loans that were high-CLTV. That is, in 2007, the median lender's new originations were $30.7 \%$ high-CLTV.

Panel A: Distributions of the Fraction of Loans Each Lender Makes that are FHA or VA

\begin{tabular}{cccccc}
\hline Year & $5^{\text {th }}$ Percentile & $25^{\text {th }}$ Percentile & $50^{\text {th }}$ Percentile & $75^{\text {th }}$ Percentile & $95^{\text {th }}$ Percentile \\
\cline { 2 - 6 } 2001 & $0.0 \%$ & $0.0 \%$ & $9.1 \%$ & $36.8 \%$ & $78.7 \%$ \\
2002 & $0.0 \%$ & $0.0 \%$ & $6.5 \%$ & $30.9 \%$ & $68.9 \%$ \\
2003 & $0.0 \%$ & $0.0 \%$ & $3.8 \%$ & $25.0 \%$ & $62.3 \%$ \\
2004 & $0.0 \%$ & $0.0 \%$ & $2.3 \%$ & $17.8 \%$ & $53.9 \%$ \\
2005 & $0.0 \%$ & $0.0 \%$ & $1.4 \%$ & $12.0 \%$ & $44.7 \%$ \\
2006 & $0.0 \%$ & $0.0 \%$ & $1.0 \%$ & $11.9 \%$ & $45.2 \%$ \\
2007 & $0.0 \%$ & $0.0 \%$ & $1.8 \%$ & $14.7 \%$ & $50.0 \%$ \\
\hline \hline
\end{tabular}

Panel B: Distributions of the Fraction of Loans Each Lender Makes that have CLTVs > 95\%

\begin{tabular}{cccccc}
\hline Year & $5^{\text {th }}$ Percentile & $25^{\text {th }}$ Percentile & $50^{\text {th }}$ Percentile & $75^{\text {th }}$ Percentile & $9^{\text {th }}$ Percentile \\
\cline { 2 - 6 } 2001 & $0.0 \%$ & $7.5 \%$ & $25.0 \%$ & $45.7 \%$ & $83.6 \%$ \\
2002 & $0.0 \%$ & $7.9 \%$ & $24.1 \%$ & $42.9 \%$ & $76.0 \%$ \\
2003 & $0.0 \%$ & $7.5 \%$ & $22.8 \%$ & $41.3 \%$ & $75.0 \%$ \\
2004 & $0.0 \%$ & $7.8 \%$ & $22.1 \%$ & $38.2 \%$ & $70.0 \%$ \\
2005 & $0.0 \%$ & $9.5 \%$ & $22.8 \%$ & $38.3 \%$ & $69.8 \%$ \\
2006 & $0.0 \%$ & $13.6 \%$ & $29.2 \%$ & $45.3 \%$ & $75.0 \%$ \\
2007 & $0.0 \%$ & $14.7 \%$ & $30.7 \%$ & $46.2 \%$ & $75.0 \%$ \\
\hline \hline
\end{tabular}




\section{A Online Appendix - Supplemental Tables}

\section{Figure A1: Use of Junior Liens Over Time}

This figure plots the share of all home purchases financed, as per the deeds records, with more than one mortgage among home purchases financed with at least one mortgage. These second and third mortgages are often called "piggyback" mortgages.

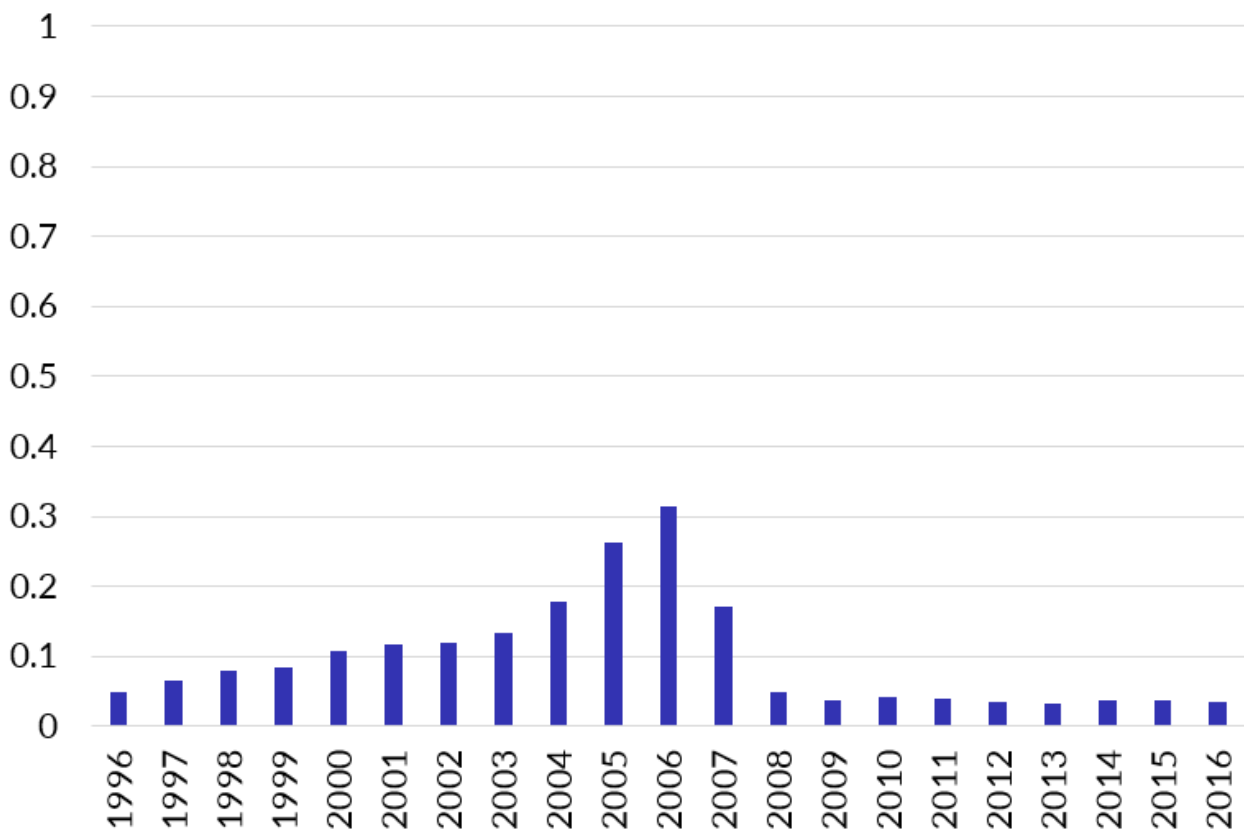




\section{Figure A2: Cash Purchases Over Time}

This figure plots the share of all home purchases financed, as per the deeds records, with $100 \%$ cash.

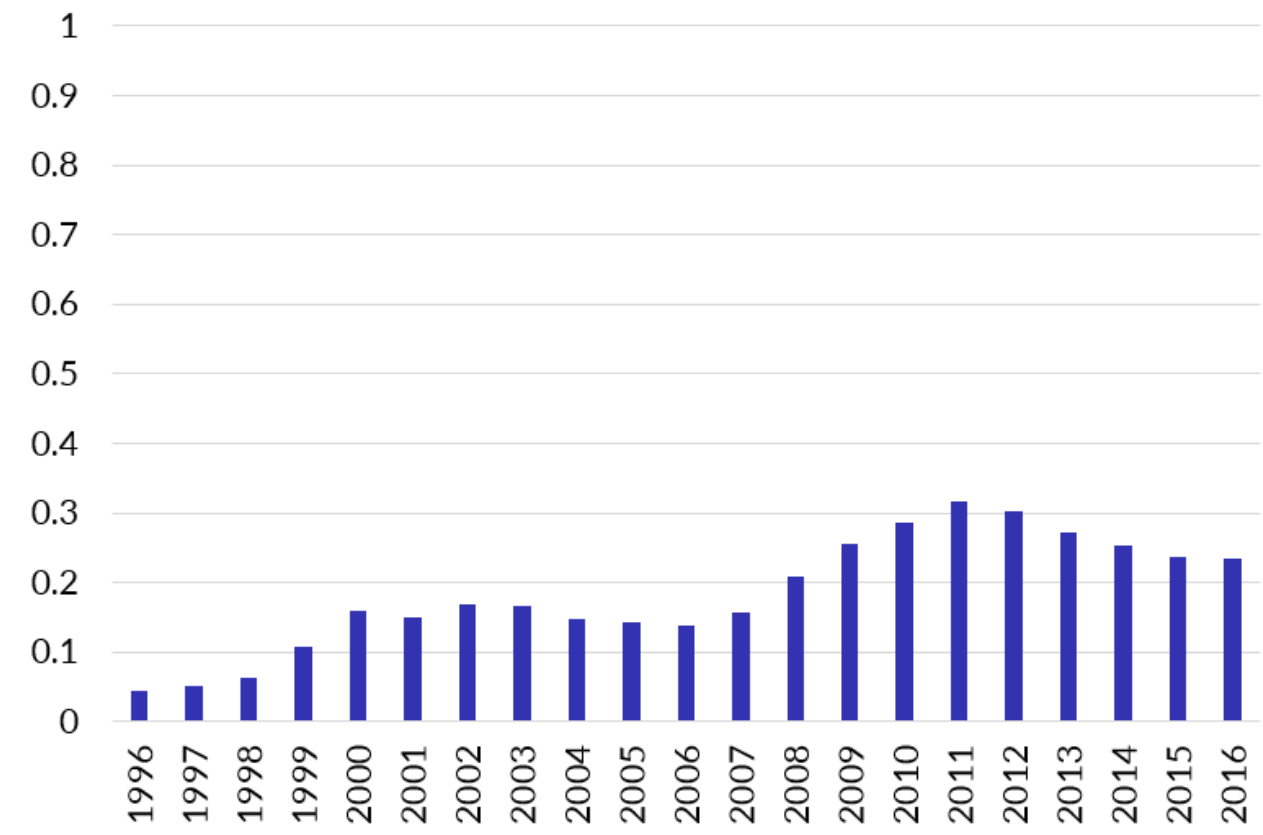


Figure A3: Frequency of New Purchase Mortgage Originations over Time

This figure plots the frequency of all home purchases financed with mortgages between 1996 and 2015.

$3,500,000$

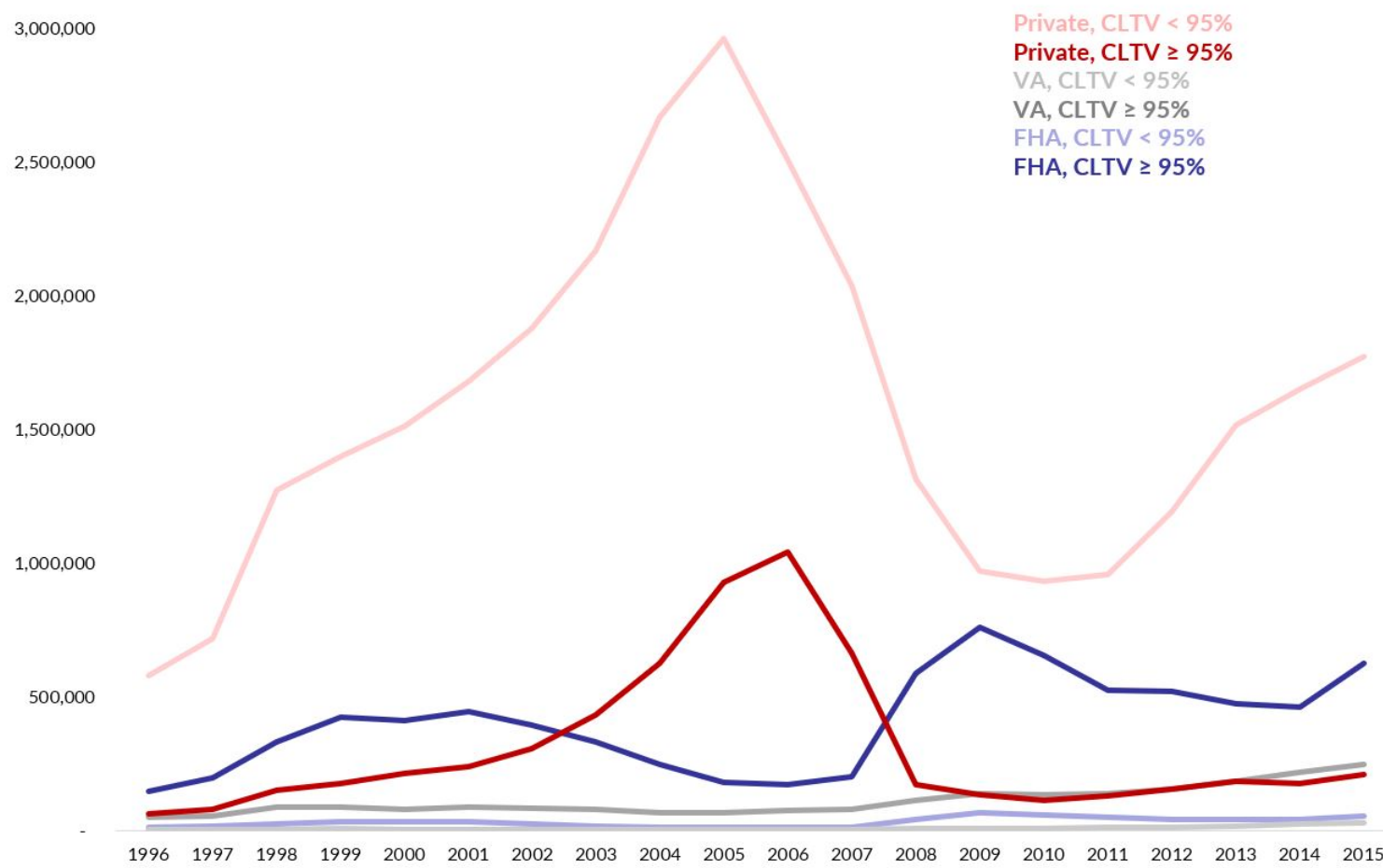




\section{Figure A4: Value-Weighted Distributions of Purchase Loan CLTV Ratios Over Time}

This figure plots the combined loan-to-value ratios (CLTVs) of the universe of purchase transactions financed with at least some debt covered in the CoreLogic deeds data between 1996 and 2015. Loans are weighted by loan amount. Each purchase transaction includes data on up to three mortgages, one primary mortgage and up to two piggyback mortgages. The percentiles and mean are calculated using all purchase loans originated in the calendar year.

\section{Weighted by Loan Amount}

$110 \%$

$100 \%$

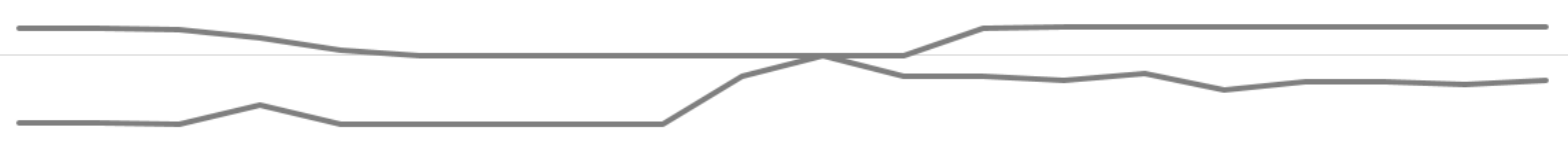

95 $5^{\text {th }}$ Percentile $75^{\text {th }}$ Percentile

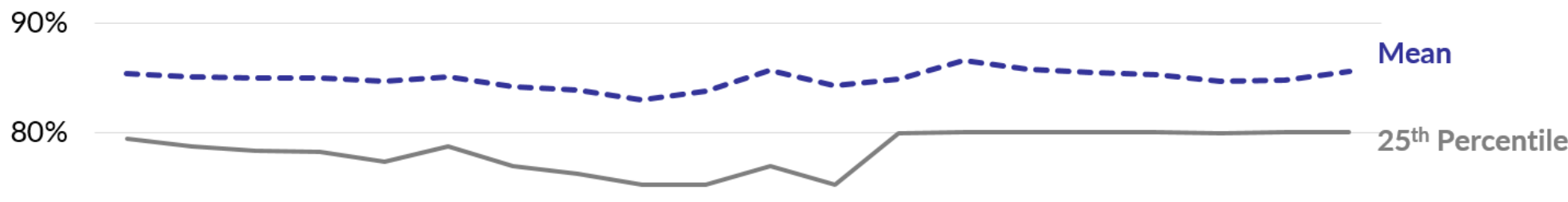

$70 \%$

$60 \%$

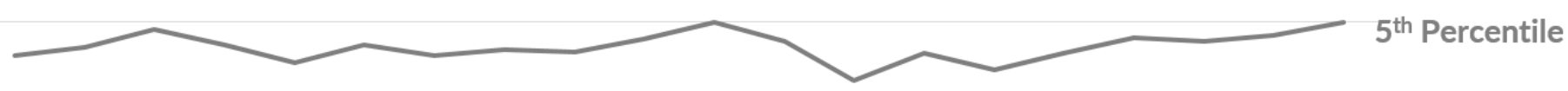

$50 \%$

$40 \%$
익 aे a 


\section{Figure A5: A Changing Share of Government-Guaranteed Mortgages}

To produce this figure, purchase loans are grouped into one of five types, the four explicitly plotted below and everything else. The figure plots the share of each type totaling up to $100 \%$ of all purchase loans. Data is from CoreLogic.

0.6

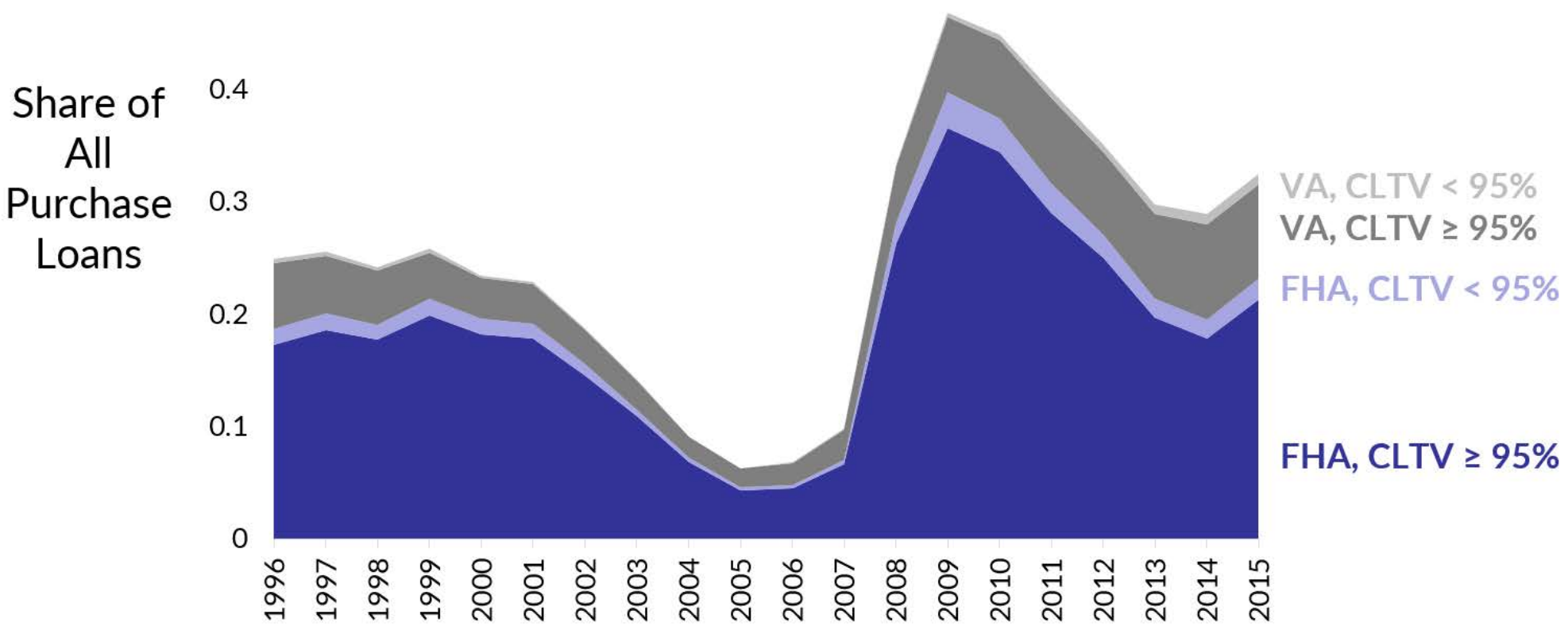




\section{Figure A6: Comparing Low- and High-HP Growth Regions}

These figures plot the combined loan-to-value ratios (CLTVs) of the universe of purchase transactions financed with at least some debt covered in the CoreLogic deeds data between 1996 and 2015. Each purchase transaction includes data on up to three mortgages, one primary mortgage and up to two piggyback mortgages. The percentiles and mean are calculated using all purchase loans originated in the calendar year. States are classified as low-HP growth regions corresponding to the bottom two deciles of house price growth between June of 2002 and June of 2006 (left panel), or high-HP growth regions, corresponding to the top two deciles (right panel).

Panel A: Bottom 2 HP Growth Deciles

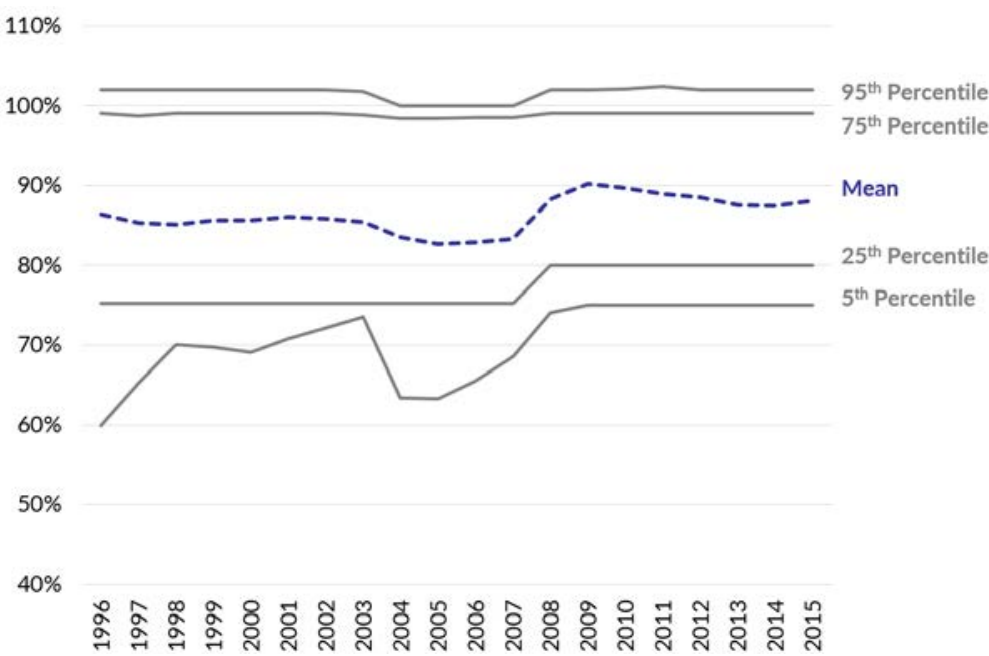

Panel B: Top 2 HP Growth Deciles

$110 \%$

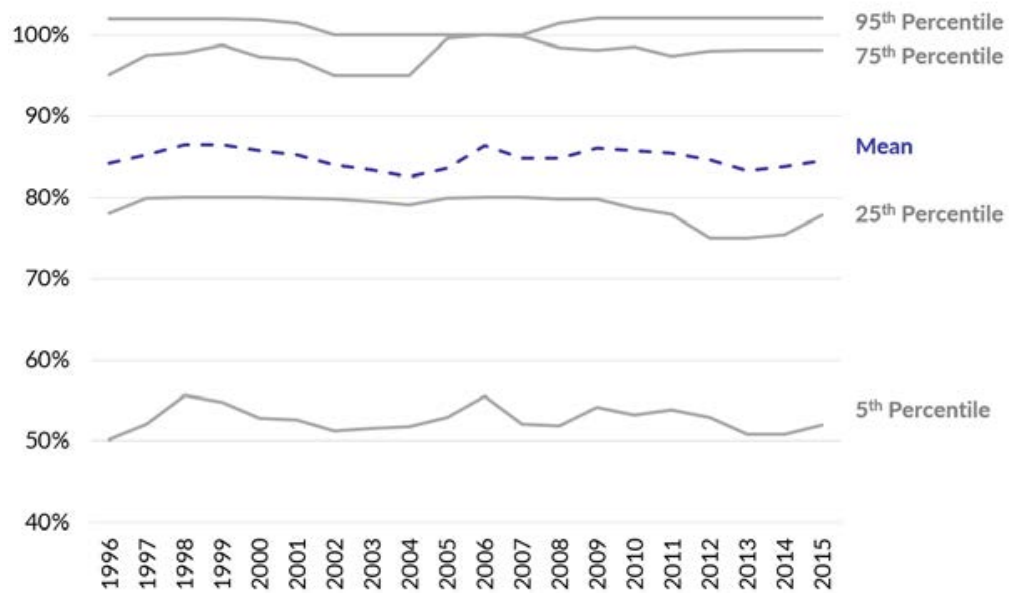




\section{Figure A7: Comparing Recourse and Non-Recourse States}

These figures plot the combined loan-to-value ratios (CLTVs) of the universe of purchase transactions financed with at least some debt covered in the CoreLogic deeds data between 1996 and 2015. Each purchase transaction includes data on up to three mortgages, one primary mortgage and up to two piggyback mortgages. The percentiles and mean are calculated using all purchase loans originated in the calendar year. States are classified as either recourse (left panel) or non-recourse (right panel).
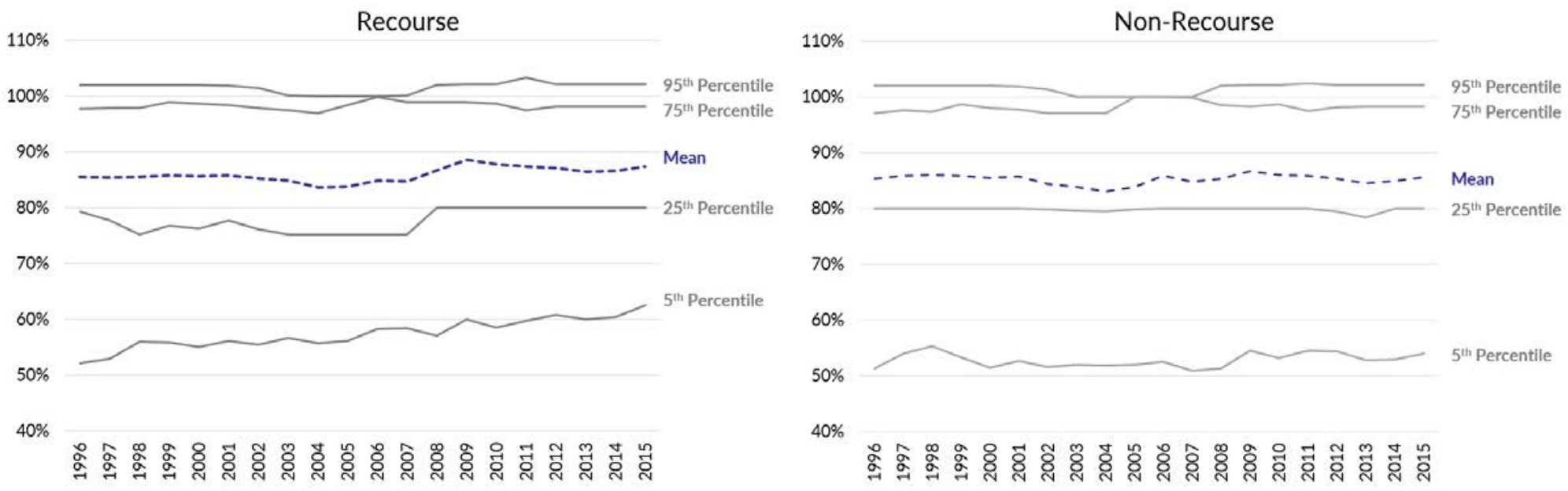


\section{Figure A8: CLTV Repeat Sales Index (Relative to 2001 Baseline)}

This figure plots a CLTV repeat sales index relative to a 2001 baseline. The construction is analogous to the standard house price index. CLTVs of purchase loans are regressed on year fixed effects and, importantly, property fixed effects. In this way, CLTV differences are calculated using only within-property variation over time. The estimates and standard errors of each year's effect are graphed below.

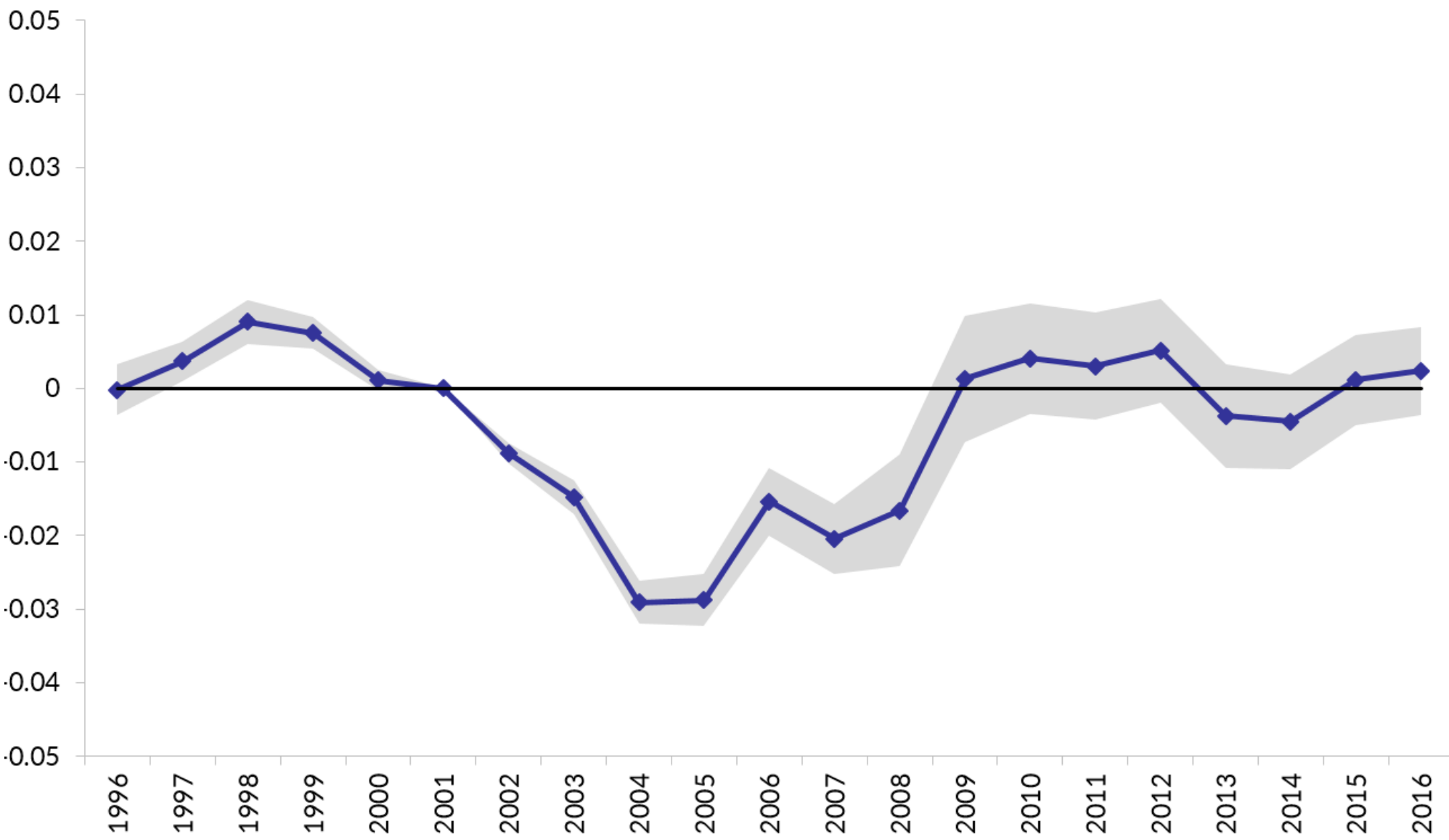


Figure A9: CLTV Lender-by-County Index (Relative to 2001 Baseline)

This figure plots a CLTV index relative to a 2001 baseline. Instead of property fixed effects as used in Figure A8, this figure includes lender-by-county fixed effects. In this way, CLTV differences are calculated using only variation with lender-by-county loans over time. The estimates and standard errors of each year's effect are graphed below.

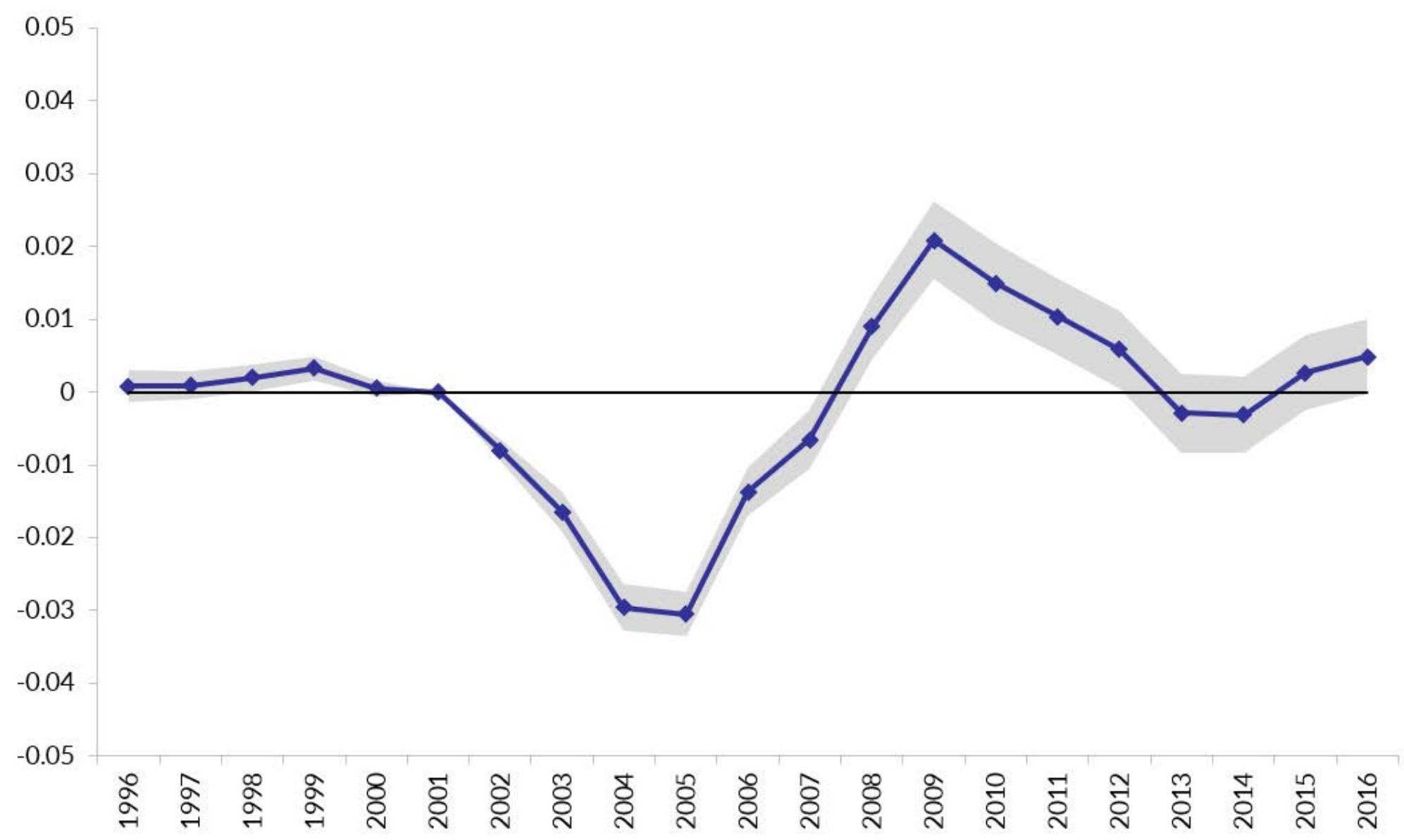




\section{Figure A10: Debt-to-Income by Loan-to-Value, 2011-2015 Originations}

Figure shows point estimates and standard errors for debt-to-income levels regressed on loan-to-value bin indicators. Figure only includes full documentation loans and loans with a combined loan-to-value ratio above 90\%. Data comes from First American LoanPerformance, McDash Analytics.

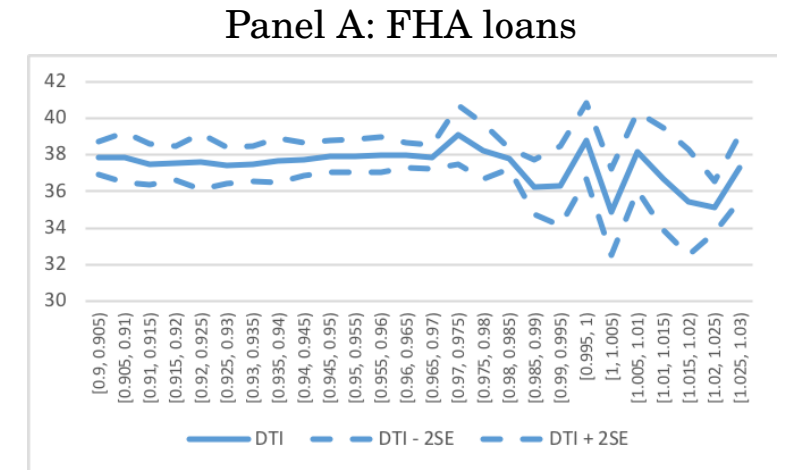

Panel C: Non-FHA loans, $660<$ Credit score $\leq 720$

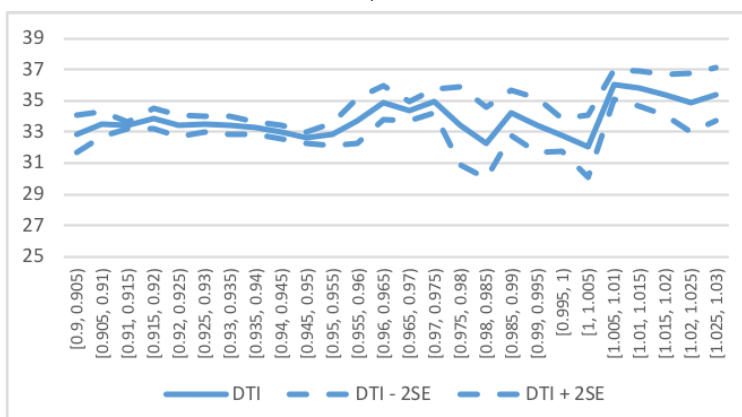

Panel B: Non-FHA loans, Credit score $\leq 660$

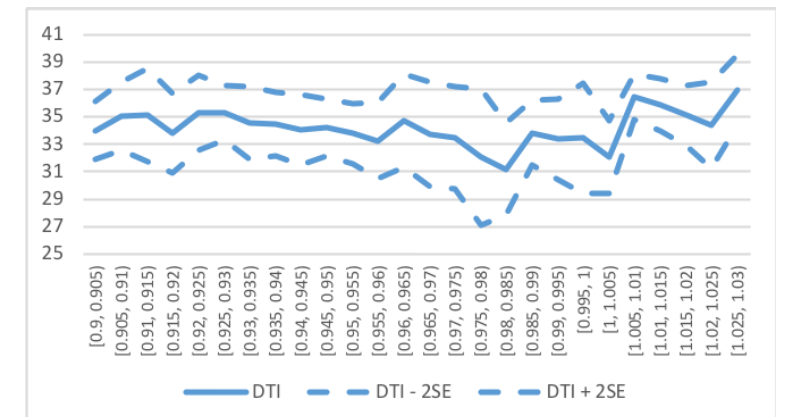

Panel D: Non-FHA loans, Credit score > 720

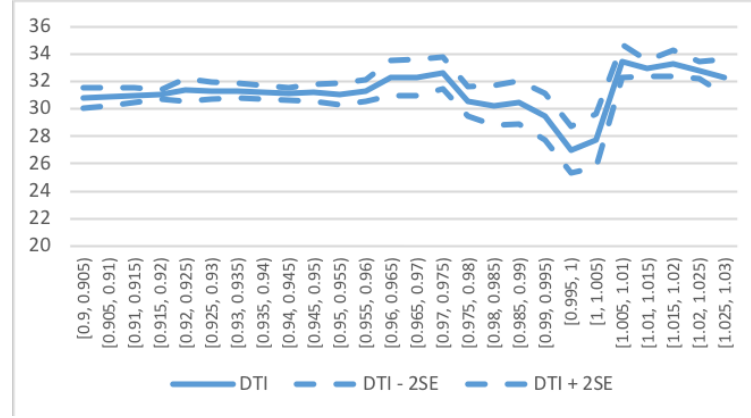




\section{Figure A11: Optimism and outlook on the economy}

Figure shows the percentage of individuals who believe the economy will improve over the subsequent 12 months. Optimism is measured using a residual of life expectancy after controlling for year fixed effects, as well as observable individual characteristics like age, income, education, gender, smoker status and perceived health status. Deciles are formed using survey weights. Data is from the Survey of Consumer Finances (SCF) waves between 1998 and 2016.

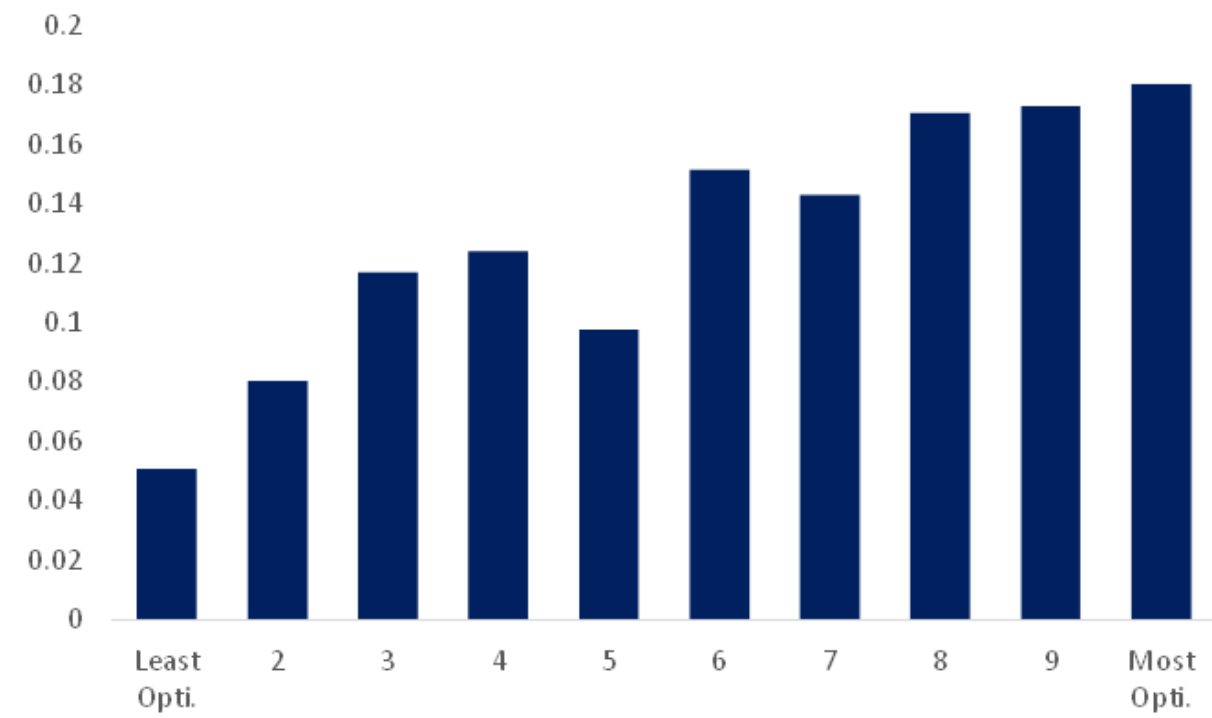




\section{Figure A12: Do Optimists Choose Higher LTV Loans}

Data is from the Survey of Consumer Finances (SCF). Optimism is measured using as in Puri and Robinson (2007). The pre-period uses SCF waves 1995, 1998, and 2001. The boom period uses SCF waves 2004 and 2007; Bust 2010 wave, and Post 2013 and 2016 waves. High-LTV borrowers are those who report outstanding mortgage balances valued at more than $80 \%$ of the value of their home, low-LTV otherwise.

\section{High LTV Borrowers}

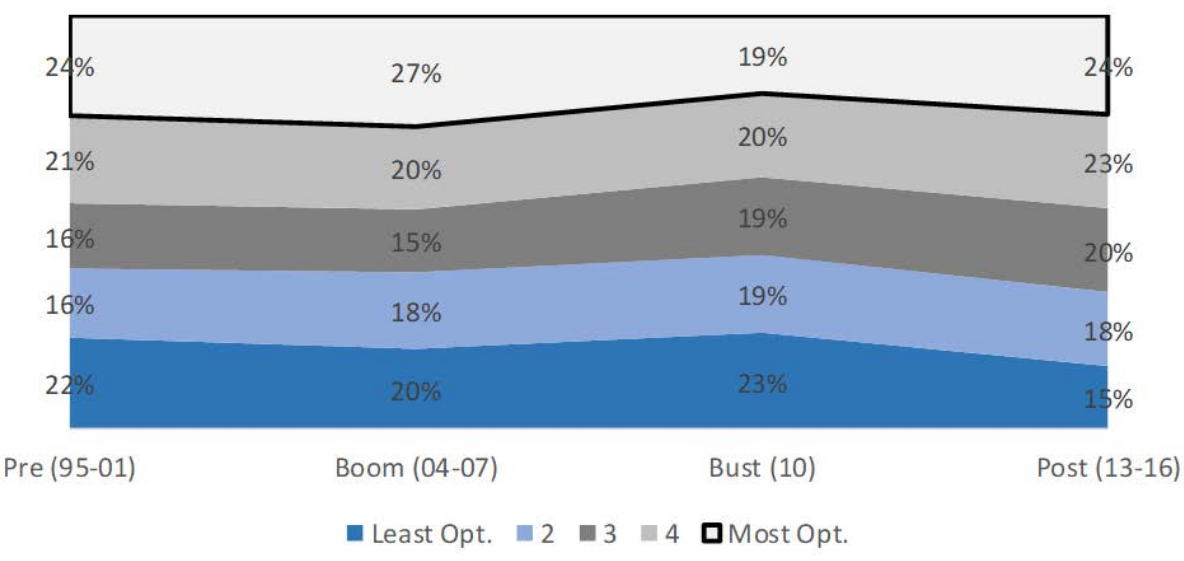

Low LTV Borrowers

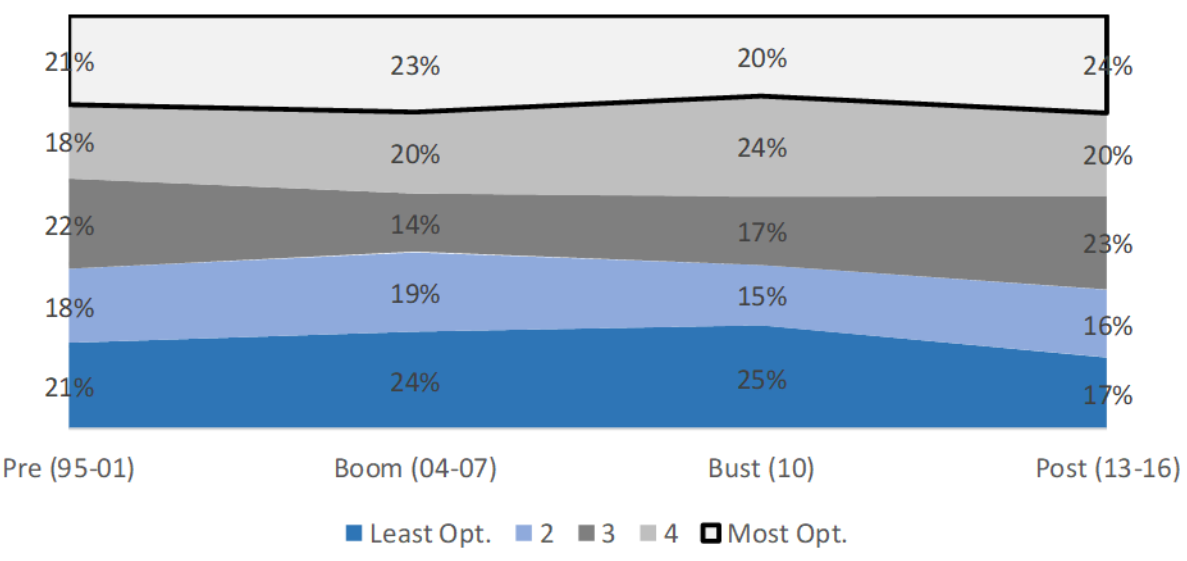




\section{Figure A13: Income-by-optimism choice of High-LTV Loans}

Table shows the share of households purchasing a home in the last two years with a highLTV loan (FHA or private) in each period. High-LTV borrowers are those who report outstanding mortgage balances valued at more than $80 \%$ of the value of their home. Shares sum to one by income quintile. Optimism is measured using a residual of life expectancy after controlling for year fixed effects, as well as observable individual characteristics like age, income, education, gender, smoker status and perceived health status. The pre-period uses SCF waves 1995, 1998, and 2001. The boom period uses SCF waves 2004 and 2007. Quintiles of income and optimism are formed using survey weights.
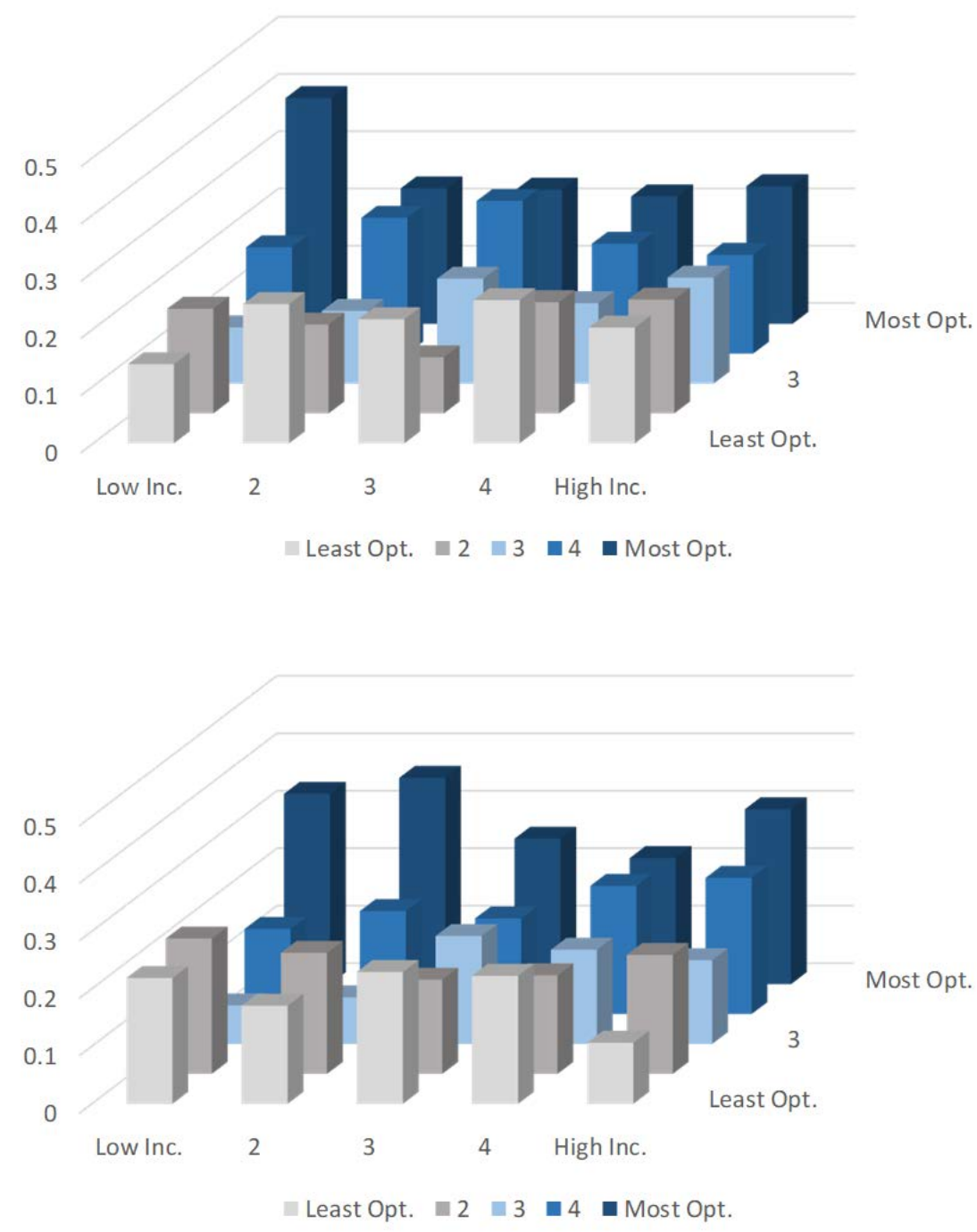